\title{
Analyses of Quantum Chemical Parameters, Fukui Functions, Magnetic Susceptibility, Hyperpolarizability, Frontier Molecular Orbitals, NBO, Vibrational and NMR Studies of 1(4- Aminophenyl) Ethanone
}

\author{
M. Karunanidhi ${ }^{1}$, V. Balachandran ${ }^{2}$, B. Narayana ${ }^{3}$, M. Karnan ${ }^{4}$ \\ ${ }^{1,4}$ Department of Physics, Srimad Andavan Arts and Science College (Autonomous), Tiruchirappalli 620005, India \\ ${ }^{2}$ Centre for Research, Department of Physics, A.A. Government Arts College, Musiri 621211, India \\ ${ }^{3}$ Department of Studies in Chemistry, Mangalore University, Mangalagangotri 574 199, India
}

\begin{abstract}
Various quantum chemical parameters such as ionization potential, electron affinity, chemical hardness, electro negativity, local softness, chemical potential and the appropriate local quantities of 1(4-Aminophenyl)ethanone (APE) have been calculated. The entire quantum chemical calculations and optimized structural parameters (bond lengths and bond angles), vibrational frequencies and optimized geometry have performed at DFT/B3LYP method with cc-pVDZ and cc-pVTZ basis sets using the Gaussian 09W program package. The FTIR and FT Raman spectra of 1(4-Aminophenyl)ethanone have been recorded in the regions $4000-400 \mathrm{~cm}^{-1}$ and 3500 - $100 \mathrm{~cm}^{-1}$, respectively. The calculated harmonic vibrational frequencies have been compared with experimental FTIR and FT Raman spectra. The observed and calculated frequencies are found to be in good agreement. The effects of substituent (amino and acetyl groups) on the benzene ring vibrational frequencies are analyzed. ${ }^{1} \mathrm{H}$ and ${ }^{13} \mathrm{C} N \mathrm{NR}$ isotropic chemical shifts are calculated and assignments made are compared with the experimental values. Magnetic susceptibility and thermodynamic properties have been determined for various range of temperature. The energies of frontier molecular orbitals, hyperpolarizability, total electron density and electrostatic potential of the title compound are determined. Mulliken analysis on atomic charges, local reactivity descriptors such as local softness $\left(s_{k}\right)$,Fukui function $\left(f_{k}\right)$, global electrophilicity and nucleophilicity of the title compound have also been calculated.
\end{abstract}

Keywords: Quantum chemical parameters, Magnetic susceptibility, Fukui function, 1(4-Aminophenyl) ethanone, Hyperpolarizability, Thermodynamic properties

\section{Introduction}

Acetophenone occurs naturally in many foods including apple, cheese, apricot, banana and cauliflower. Commercially significant resins of acetophenone with formaldehyde and base resulting polymers are used as components of coatings, adhesives and inks. Acetophenone is used to create fragrances that correspond to almond, cherry, honeysuckle, jasmine and strawberry. It is used in medicine; it was marketed as a hyptonic and anticonvulsant under the brand name hypnone. Chloro acetophenone is primarily used as a riot-control agent (tear gas) and in Chemical Mace [1,2]. Hydroxyacetophenone is used as a building block for the synthesis of rubbers, plastics, pharmaceuticals, agrochemicals, flavor and fragrances. In pharmaceuticals hydroxyacetophenone is employed as an intermediate for the synthesis of medicine named as propafenone which is used for curing arrhythmia [3]. Recent studies revealed that studies of aminophenylacetophenone and their complexes have received most of attention, because of magnetic, spectroscopic, biological and photosensitive properties. Aminophenylacetophenone have shown a wide variety of anticancer, antimicrobial, antifungal, antidepressant antitumor, antibacterial, antiinflammatory and anticonvulsant activities [4].
The vibrational analyses of this molecule would be helpful for understanding the various types of bonding and normal modes of vibration. In recent trends, the quantum chemical computational methods have proved to be an essential tool in analyzing the vibrational spectra. Subramanian et al.[5], have extensively studied the thermodynamic properties of 3aminoacetophenone. Seth et al. [6] investigated the spectroscopic and X-ray structure of ortho-hydroxy acetophenones. Pei et al. [7] investigated the FranckCondon region photodissociation dynamics of $p$ nitroacetophenone using resonance Raman spectroscopy and density functional theory calculations. Literature survey reveals that to the best of our knowledge no DFT/B3LYP method with cc-pVDZ and cc-pVTZ basis sets and magnetic susceptibility, fukui function, thermodynamic calculations, and experimental (FT-IR, FT-Raman and NMR) investigation of APE are reported so far. Therefore, an attempt has been made in the present work to study the detailed theoretical DFT/B3LYP method with cc-pVDZ and cc-pVTZ basis sets and magnetic susceptibility, fukui function, thermodynamic properties, and experimental (FTIR and FT Raman, ${ }^{1} \mathrm{H}$ and ${ }^{13} \mathrm{C}$ NMR) spectral investigation of APE. 


\section{International Journal of Science and Research (IJSR) \\ ISSN (Online): 2319-7064}

Index Copernicus Value (2015): 78.96 | Impact Factor (2015): 6.391

\section{Experimental Details}

The sample APE in the solid form was purchased from the Lancaster Chemical Company, (UK) with a purity of greater than $97 \%$ and it was used as such without further purification. The Fourier transform infrared (FT-IR) spectrum of the sample was recorded at room temperature in the region 4000-400 $\mathrm{cm}^{-1}$ using Perkin-Elmer spectrum RX1 spectrophotometer equipped with composition of the pellet.The signals were collected for 100 scans with a scan interval of $1 \mathrm{~cm}^{-1}$ and at optical resolution of $0.4 \mathrm{~cm}^{-1}$. The Fourier transform Raman (FT-Raman) BRUKER-RFS 27 spectrometer was used for the Raman spectral measurements at room temperature. The spectrometer consisted of a quartz beam splitter and a high sensitive germanium diode detector cooled to the liquid nitrogen temperature. The sample was packed in a glass tube of about $5 \mathrm{~mm}$ diameter and excited in the $180^{\circ}$ geometry with $1064 \mathrm{~nm}$ laser line at $100 \mathrm{~mW}$ power from a diode pumped air cooled-cw Nd:YAG laser as an excitation wavelength in the region $4000-100 \mathrm{~cm}^{-1}$. The signals were collected for 300 scans at the interval of $1 \mathrm{~cm}^{-1}$ and optical resolution of $0.1 \mathrm{~cm}^{-1}$.

\subsection{NMR spectroscopy}

Nuclear magnetic resonance (NMR) spectra were recorded on a Bruker 300 AVANCE spectrometer at $300 \mathrm{MHz}$ for ${ }^{1} \mathrm{H}$ and $75 \mathrm{MHz}$ for ${ }^{13} \mathrm{C}$ in $\mathrm{CDCl} 3$ solutions containing 0.03 vol.\% TMS as internal standard.

\subsection{Methods of computation}

The entire quantum chemical calculations have performed at DFT/B3LYP method with cc-pVDZ and cc-pVTZ basis sets using the Gaussian $09 \mathrm{~W}$ program package [8]. The optimized structural parameters have been evaluated for the calculation of vibrational frequencies at Becke's three parameter hybrid model using the Lee-Yang-Parr $[9,10]$ correlation functional (B3LYP) method. As a result, the unscaled calculated frequencies, infrared intensity, Raman activity, are obtained. In order to fit the theoretical frequencies to the experimental frequencies, an overall scaling factor has been introduced by using a least-square optimization. The vibrational frequencies are scaled as 0.9899 for frequencies less than $1700 \mathrm{~cm}^{-1}$ and 0.9552 for higher frequencies for B3LYP. After scaled with the scaling factor, the deviation from the experiments is less than $10 \mathrm{~cm}$ ${ }^{1}$ with a few exceptions. The assignments of the calculated normal modes have been made on the basis of the corresponding PEDs. The PEDs are computed from quantum chemically calculated vibrational frequencies using MOLVIB program version 7.0 written by Sundius $[11,12]$. Gauss view program [13] has been considered to get visual animation and also for the verification of the normal modes assignment.

\subsection{Prediction of Raman intensities}

The Raman activities $\left(\mathrm{S}_{\mathrm{i}}\right)$ calculated with the help of GAUSSIAN 09 program were converted to relative Raman intensities $\left(\mathrm{I}_{\mathrm{i}}\right)$ using the following relationship derived from the basic theory of Raman scattering [14-16]. $\mathrm{I}_{\mathrm{i}}=\mathrm{f}\left(\mathrm{v}_{0}-v_{\mathrm{i}}\right)^{4} \mathrm{~S}_{\mathrm{i}} /$ $v_{\mathrm{i}}\left[1-\exp \left(-h c v_{\mathrm{i}} / \mathrm{kt}\right)\right]$ where $v_{0}$ is the laser exciting frequency in $\mathrm{cm}^{-1}$ (in this work, we have used the excitation wave number $v_{0}=9398.5 \mathrm{~cm}^{-1}$, which corresponds to the wavelength of $1064 \mathrm{~nm}$ of a $\mathrm{Nd}$ :YAG laser), $v_{i}$ is the vibrational wave number of the $i^{\text {th }}$ normal mode $\left(\right.$ in $\left.\mathrm{cm}^{-1}\right)$ and $\mathrm{S}_{i}$ is the Raman scattering activity of the normal mode $v_{i}, f$ (is the constant equal to $10^{-12}$ ) is the suitably chosen common normalization factor for all peak intensities. $\mathrm{h}, \mathrm{k}$, c, and $\mathrm{T}$ are Planck constant, Boltzmann constant, speed of light and temperature in Kelvin, respectively.

\section{Structural properties}

The optimized stable geometry and the scheme of atom numbering of the compound APE are represented in Fig.1. The optimized structural parameters bond length, bond angle and the dihedral angle for the more stable geometry of APE determined at B3LYP with cc-pVDZ and cc-pVTZ basis sets are presented in Table 1. The influence of the substituent on the molecular parameters, particularly in the $\mathrm{C}-\mathrm{C}$ bond distance of ring carbon atoms seems to be varied. The mean bond length of aromatic ring is $1.40 \AA$. The longer bond length $(1.48 \AA)$ of $\mathrm{C} 1-\mathrm{C} 7$ is due to the absence of delocalization of carbonyl lone pair of electrons towards the ring. Similarly, the bond C7-C9 has $1.52 \AA$ because of the hyper conjugative effect of the methyl group and due to the partial ionic character of the $\mathrm{C}-\mathrm{O}$ group, decreases in force constant and increase in bond length. The bond length of C7-O8 and C7-C9 are 1.22 and $1.52 \AA$, respectively shows an excellent results with the bond length of 4-hydroxy 3methoxyacetophenone [17]. While the bond length C7-O8 $(1.22 \AA)$ of $2 \mathrm{H} 4 \mathrm{MAP}$ is elongated with respect to acetophenone (C-O; 1.216 $)$ [18]. But in the case APE the orientations of the carbonyl, methyl and amino groups with respect to the aromatic ring are perfectly planar. This is confirmed by the dihedral angle, C7-C1-C2-C $3 ;-180^{\circ}, \mathrm{C} 7-$ $\mathrm{C} 1-\mathrm{C} 6-\mathrm{C} 5 ; 180^{\circ}$, C6-C1-C7-C9; 180 ${ }^{\circ}, \mathrm{C} 2-\mathrm{C} 1-\mathrm{C} 7-\mathrm{C} 9 ; 0^{\circ}$, C2-C3-C4-N15; -180 ${ }^{\circ}$, N15-C4-C5-C6; 180 . Analyzing the bond angle of aromatic ring of APE, one can observe that the geometry of the benzene ring is seen to be relatively perturbed due to the presence of different substituent's. With the electron donating and withdrawing substituent's on the benzene ring, the symmetry of the ring is distorted, yielding variation in bond angles at the point of substitution and at the ortho and meta positions as well. The studies indicated that the interior bond angle, at the carbon to which a methyl or amino group is attached, is invariably smaller than that normally adopted as the interior bond angle of the benzene ring $[19,20]$. On the other hand, the interior bond angle at the carbon to which a nitro group is attached invariably exceeds the normal $120^{\circ}[21]$. The bond angle C2-C1-C6 is $117.7^{\circ}$ where the $-\mathrm{COCH}_{3}$ group is attached while at ortho positions the bond angle $\mathrm{C} 1-\mathrm{C} 2-\mathrm{C} 3$ is found to be $121.3^{\circ}$ while the bond angle $\mathrm{C} 1-\mathrm{C} 6-\mathrm{C} 5$ is $121.5^{\circ}$. This indicates that the inner bond angle is less than $120^{\circ}$ where the electron withdrawing acetyl group attached while the inner ortho bond angles are more than $120^{\circ}$. This is also due to the predominance of the partial ionic nature of the carbonyl group. Similarly, the bond angle C3-C4-C5 where the amino group attached is $118.2^{\circ}, 118.4^{\circ}$. These are determined by B3LYP/ cc-pVDZ and cc-pVTZ method.

Volume 6 Issue 1, January 2017

www.ijsr.net

Licensed Under Creative Commons Attribution CC BY 


\section{International Journal of Science and Research (IJSR) \\ ISSN (Online): 2319-7064}

Index Copernicus Value (2015): 78.96 | Impact Factor (2015): 6.391

\section{Vibrational Analysis}

The geometry of the molecule is possessing Cs point group symmetry. The 51 fundamental modes of vibrations are span into 35 in-plane modes of $\mathrm{A}^{\prime}$ and 16 out-of-plane bending vibrations of $\mathrm{A}^{\prime \prime}$ species. The observed and calculated FTIR and FT-Raman spectra of APE are shown in Figs. 2 and 3. The observed FTIR and FT-Raman wavenumbers along with the theoretical IR and Raman frequencies along with their relative intensities and probable assignments are summarized in Table 2.

\subsection{Skeletal stretching vibrations}

The carbon-carbon vibrations are more interesting if the double bond is in conjugation with the ring. The actual positions of the C-C stretching modes are determined not so much by the nature of substituent but by the form of the substitution around the ring $[22,23]$. The $\mathrm{C}-\mathrm{C}$ bands which indicate aromatic properties of benzene derivatives mainly occur within the range of $1640-1200 \mathrm{~cm}^{-1}$. The strong bands observed in the infrared spectrum at $1565,1360 \mathrm{~cm}^{-1}$ and in Raman spectrum the medium lines observed at 1612 , $1564 \mathrm{~cm}^{-1}$ are assigned to the C-C stretching modes of APE. The modes observed at 960, 958, 823, 733, 636, 564, 560, $469,335 \mathrm{~cm}^{-1}$ in infrared and Raman spectra are assigned to the $\mathrm{C}-\mathrm{C}-\mathrm{C}$ in-plane ring trigonal bending vibration. The other in-plane bending vibrations are assigned to the modes at 574, 456 and $417 \mathrm{~cm}^{-1}$. The C-C-C out-of-plane bending modes are attributed to the low Raman frequencies [24].

\subsection{C-H vibrations}

The aromatic C-H stretching vibrations are normally found between 3100 and $3000 \mathrm{~cm}^{-1}$ [25]. In this region the bands are not affected appreciably by the nature of substituent. The aromatic $\mathrm{C}-\mathrm{H}$ stretching vibrations present in the benzene ring of APE are seen in the infrared spectrum as medium bands at 3086 and $3063 \mathrm{~cm}^{-1}$ and in Raman spectrum the medium lines observed at 3065, 3046 and $3025 \mathrm{~cm}^{-1}$. The aromatic $\mathrm{C}-\mathrm{H}$ in-plane bending modes of benzene and its derivatives are observed in the region $1300-1000 \mathrm{~cm}^{-1}$. The peaks seen at 1514, 1437, 1173 and $1134 \mathrm{~cm}^{-1}$ in IR spectrum and $1516,1441,1171 \mathrm{~cm}^{-1}$ in Raman spectrum belongs to the aromatic $\mathrm{C}-\mathrm{H}$ in-plane bending vibrations. The C-H out-of-plane bending mode of benzene derivatives are observed in the region $1100-600 \mathrm{~cm}^{-1}$. The aromatic C-H out-of-plane bending vibrations of APE are seen in the Raman spectrum at 943, 901, 811 and $785 \mathrm{~cm}^{-1}$.

\subsection{Methyl group vibrations}

The methyl substituted $\mathrm{C}-\mathrm{H}$ stretching vibrations usually appears below the range of aromatic $\mathrm{C}-\mathrm{H}$ stretching. Methyl group vibrations are generally referred to as electron donating substituent in the aromatic rings system, the asymmetric C-H stretching mode of $\mathrm{CH}_{3}$ is expected around $2980 \mathrm{~cm}^{-1}$ and the $\mathrm{CH}_{3}$ asymmetric stretching is expected at $2870 \mathrm{~cm}^{-1}[26,27]$. The weak bands observed in the infrared spectrum at $2842,2819 \mathrm{~cm}^{-1}$ and in Raman spectrum the weak line observed at $2975 \mathrm{~cm}^{-1}$ are assigned to the $\mathrm{CH}_{3}$ stretching modes of APE. The theoretically calculated values by B3LYP/cc-pVDZ method at 2975, 2843,
$2824 \mathrm{~cm}^{-1}$ and B3LYP/cc-pVTZ method at 2973, 2840, 2820 $\mathrm{cm}^{-1}$ are coherent with the literature data. The asymmetric and symmetric deformation vibrations of methyl group appear within the region $1465-1440 \mathrm{~cm}^{-1}$ and 1390 $1370 \mathrm{~cm}^{-1}$ [26]. In the present investigation, the bands at $1304 \mathrm{~cm}^{-1}$ in infrared with medium intensity 1386,1375 and $1305 \mathrm{~cm}^{-1}$ in Raman with strong intensity are observed as $\mathrm{CH}_{3}$ asymmetric deformation and symmetric deformation vibrations. The theoretically calculated values by B3LYP/cc-pVDZ method at 1389,1378 and $1312 \mathrm{~cm}^{-1}$ shows good agreement with experimental values. The methyl rocking mode vibration usually appears within the region $1070-1010 \mathrm{~cm}^{-1}$ [27]. With reference to literature data, a band observed at $1073,1035 \mathrm{~cm}^{-1}$ in Raman spectrum and $1073,1035 \mathrm{~cm}^{-1}$ in FT-IR are assigned $\mathrm{CH}_{3}$ rocking vibration. The DFT calculation gives rocking vibration at 1079 and $1038 \mathrm{~cm}^{-1}$ and $1074,1029 \mathrm{~cm}^{-1}$ are quiet fit with experimental values. Torsional modes of vibrations are observed at very low frequencies. The computed frequency at $161,145 \mathrm{~cm}^{-1}$ are assigned to torsional mode of vibration.

\section{4. $\mathrm{C}=\mathrm{O}$ vibrations}

The characteristic infrared absorption frequency of $\mathrm{C}=\mathrm{O}$ in acids are normally strong in intensity and found in the region $1800-1690 \mathrm{~cm}^{-1}$ [28]. This position of $\mathrm{C}=\mathrm{O}$ stretching more effective to analyze the various factors in ring aromatic compounds. The $\mathrm{C}=\mathrm{O}$ bond formed by $=$ bond between $\mathrm{C}$ and $\mathrm{O}$ intermolecular hydrogen bonding, reduces the frequencies of the $\mathrm{C}=\mathrm{O}$ stretching absorption to a greater degree than does intermolecular $\mathrm{H}$ bonding because of the different electro-negativities of $\mathrm{C}$ and $\mathrm{O}$, the bonding are not equally distributed between the two atoms. The loan pair of electrons on oxygen also determines the nature of the carbonyl groups. The $\mathrm{C}=\mathrm{O}$ stretching bands of acids are considerably more intense than ketonic $\mathrm{C}=\mathrm{O}$ stretching bands. In the present study the characteristic ketonic $\mathrm{C}=\mathrm{O}$ frequency appears at $1647 \mathrm{~cm}^{-1}$ in FT-IR and $1650 \mathrm{~cm}^{-1}$ in FT-Raman spectrum are assigned to $\mathrm{C}=\mathrm{O}$ stretching vibration. The calculated values of 1659 and $1653 \mathrm{~cm}^{-1}$ at B3LYP/cc-pVDZ and B3LYP/cc-pVTZ levels of theory are in good agreement with the experimental value of $\mathrm{C}=\mathrm{O}$ stretching mode. This $\mathrm{C}=\mathrm{O}$ vibration appears in the expected range shows that it is not much affected by other vibrations. Kolev[29] showed that in aromatic and aliphatic ketones, the $\mathrm{C}=\mathrm{O}$ in-plane and out-of-plane deformation modes are seen in $605-552 \mathrm{~cm}^{-1}$ and $584-285 \mathrm{~cm}^{-1}$ region, respectively. In the present study $\mathrm{C}=\mathrm{O}$ in-plane bending vibration for $\mathrm{APE}$ is observed in FT-IR spectrum at $697 \mathrm{~cm}^{-1}$ and in FT-Raman spectrum at $689 \mathrm{~cm}^{-1}$. The theoretically calculated values by B3LYP/cc-pVDZ and B3LYP/cc-pVTZ methods are 706 and $695 \mathrm{~cm}^{-1}$ shows good agreement with experimental values and also the theoretically calculated values of $\mathrm{C}=\mathrm{O}$ out-of-plane bending vibration by DFT method at 605,591 $\mathrm{cm}^{-1}$ are coherent with experimental value $596 \mathrm{~cm}^{-1}$ in FTIR spectrum.

\subsection{Amino group vibrations}

According to Socrates [30] the frequencies of amino group appear around $3500-3300 \mathrm{~cm}^{-1}$ for $\mathrm{NH}_{2}$ stretching, 1700 $1600 \mathrm{~cm}^{-1}$ for scissoring and $1150-900 \mathrm{~cm}^{-1}$ for rocking deformations. For APE the antisymmetric and symmetric

\section{Volume 6 Issue 1, January 2017




\section{International Journal of Science and Research (IJSR) \\ ISSN (Online): 2319-7064}

Index Copernicus Value (2015): 78.96 | Impact Factor (2015): 6.391

stretching modes of $\mathrm{NH}_{2}$ group were found at 3395, 3329 and $3325 \mathrm{~cm}^{-1}$ in infrared and Raman bands. The theoretically calculated values by B3LYP/cc-pVDZ and B3LYP/cc-pVTZ methods are 3398, 3341, 3394 and 3330 $\mathrm{cm}^{-1}$ shows good agreement with experimental values. The bands appeared at $1594 \mathrm{~cm}^{-1}$ in Raman spectrum was assigned to the scissoring mode of $\mathrm{NH}_{2}$ group. The $\mathrm{NH}_{2}$ rocking mode has been assigned in Raman band at 1003 $\mathrm{cm}^{-1}$ for the title compound (APE). The calculated values appear at $1604,1593 \mathrm{~cm}^{-1}$ by cc-pVDZ and cc-pVTZ respectivly are assigned to scissoring mode and 1009, 1004 $\mathrm{cm}^{-1}$ are assigned to rocking mode of vibration are also good agreement with experimental frequencies. $\mathrm{NH}_{2}$ twisting modes of APE are identified at $388 \mathrm{~cm}^{-1}$ in Raman band and the calculated values appear at $401,388 \mathrm{~cm}^{-1}$ by cc-pVDZ and cc-pVTZ respectivly are also good agreement with experimental frequencies.

\section{Analysis of molecular electrostatic potential}

Molecular electrostatic potential (MEP) mapping is very useful in the investigation of the molecular structure with its physiochemical property relationships [31-34]. Total SCF electron density surface mapped with molecular electrostatic potential (MEP) of APE determined by B3LYP/ cc-pVDZ is shown in Fig.4(a) while the contour map of the molecular electrostatic potential is given in Fig. 4(b). The MEP surface displays the molecular shape, size and electrostatic potential values. The colour scheme for the MEP surface is redelectron rich or partially negative charge; blue-electron deficient or partially positive charge; light blue-slightly electron deficient region; yellow-slightly electron rich region, respectively. The oxygen atoms have more negative potentials and the hydrogen atoms have more positive potentials. The MEP of APE clearly indicates the electron rich centre of oxygen atoms. The molecular electrostatic potential surface of APE determined by B3LYP/ cc-pVDZ method is shown in the Fig. 4(a). The minimum and maximum limits of the electrostatic potential observed in APE are $\pm 5.628 \mathrm{e}^{-10-2}$.

\section{Natural bond orbital (NBO) analysis}

Natural bond orbital (NBO) analysis is a useful tool for understanding delocalization of electron density from occupied Lewis-type (donor) NBOs to properly unoccupied non-Lewis type (acceptor) NBOs within the molecule. The stabilization of orbital interaction is proportional to the energy difference between interacting orbital. Therefore, the interaction having strongest stabilization takes place between effective donors and effective acceptors. This bonding, anti bonding interaction can be quantitatively described in terms of the NBO approach that is expressed by means of second-order perturbation interaction energy $\mathrm{E}(2)$ [35-38]. This energy represents the estimate of the offdiagonal NBO Fock matrix element. The stabilization energy $E^{(2)}$ associated with $i$ (donor) $\rightarrow j$ (acceptor) delocalization is estimated from the second-order perturbation approach as given below $\mathrm{E}^{(2)}=\mathrm{q}_{\mathrm{i}} \mathrm{F}^{(2)}(\mathrm{I}, \mathrm{j}) / \varepsilon_{\mathrm{j}}-\varepsilon_{\mathrm{i}}$ where $\mathrm{q}_{\mathrm{i}}$ is the donor orbital occupancy, $\varepsilon_{\mathrm{i}}$ and $\varepsilon_{\mathrm{j}}$ are diagonal elements (orbital energies) and $F(i, j)$ is the offdiagonal Fock matrix element. The different types of donoracceptor interactions and their stabilization energy are determined by second order perturbation analysis of Fock matrix of APE. The stabilization energy of all lone pairbond pair interactions and only bond pair-bond pair interactions are listed in Table 3. In APE molecule, the lone pair donor orbital, $\mathrm{n}_{\mathrm{N}} \rightarrow \pi^{*}{ }_{\mathrm{cc}}$ interaction between the (N15) lone pair and the $\mathrm{C} 4$ antibonding orbital gives a strong stabilization of $28.59 \mathrm{kcal} \mathrm{mol}^{-1}$. The $\mathrm{n}_{\mathrm{O}} \rightarrow \pi^{*}$ cc to the antibonding orbital $\left(\pi^{*}\right)$ of (C7) is $19.28 \mathrm{kcal} \mathrm{mol}^{-1}$. The bond pair donor $\rightarrow \pi^{*}$ stabilization energy of lone pair of electrons present in the oxygen atom orbital, $\pi_{\mathrm{N}} \rightarrow \pi^{*}{ }_{\mathrm{C}}$ interactions give more stabilization than $\pi_{\mathrm{O}} \rightarrow \pi^{*}{ }_{\mathrm{c}}$ and $\sigma_{\mathrm{cc}} \rightarrow$ $\sigma^{*}{ }_{c c}$ interactions. The analysis of the natural bond orbital of APE by DFT/B3LYP method with cc-pVDZ and cc-pVTZ basis sets is carried out to provide the occupancy, contribution to the parent NBO and mainly on the percentage contributions of the atoms present in the bond. NBO analysis of molecules illustrate the deciphering of the molecular wave function in terms Lewis structures, charge, bond order, bond type, hybridization, resonance, donoracceptor interactions, charge transfer and resonance possibility. Table.4. shows the accumulation of natural charges and electron population of atoms in core, valance, Rydberg orbitals of 1(4-Aminophenyl)ethanone. Table.5. depicts the bonding concepts such as type of bond orbital, their occupancies, the natural atomic hybrids of which the $\mathrm{NBO}$ is composed, giving the percentage of the NBO on each hybrid, the atom label and a hybrid label showing the hybrid orbital $\left(\mathrm{sp}_{\mathrm{x}}\right)$ composition (the amount of s-character, p-character, etc.) of 1(4-Aminophenyl)ethanone determined by DFT/B3LYP method with cc-pVDZ and cc-pVTZ basis sets. The occupancies of NBO's reflecting their exquisite dependence on the chemical environment. The Lewis structure that is closest to the optimized structure is determined. For example, the bonding orbital for $\mathrm{C} 1-\mathrm{C} 2$ with 1.9735 electrons has $50.41 \% \mathrm{C} 1$ character in a $\mathrm{sp}^{1.85}$ hybrid and has $49.59 \% \mathrm{C} 2$ character in a $\mathrm{sp}^{1.82}$ hybrid orbital. In the case of $\mathrm{C} 7-\mathrm{O} 8$ bonding orbital with 1.996 electrons has $33.01 \% \mathrm{C} 7$ character in a $\mathrm{sp}^{2.28}$ hybrid and has $66.99 \%$ O8 character in a $\mathrm{sp}^{1.30}$ hybrid orbital. A bonding orbital for C4-N15 with 1.990 electrons has 39.34\% C4 character in a $\mathrm{sp}^{2.93}$ hybrid and has $60.66 \%$ N15 character in a sp ${ }^{1.62}$ orbital. The $\mathrm{C}-\mathrm{C}$ bonds of the aromatic ring posses more $\mathrm{p}$ character than $\mathrm{s}$ character. This is clearly indicates the delocalization of $\mathrm{p}$ electrons among all the carbon atoms. For the title compound the dipole moment; linear polarizability and first hyperpolarizability were obtained from molecular polarizabilities based on theoretical calculations are listed in Table 6.

\section{Mullikan Atomic Charges}

Mullikan [38] atomic charge calculation has an important role for the application quantum chemical calculations (QCC) of the molecular system. Atomic charge affects dipole moment, polarizability, electronic structure and other molecular properties of the system. The calculated Mullikan charge (e) values of APE are listed in Table 7. It is clearly shown that the carbon atom attached with hydrogen atom is negative whereas the remaining carbon atoms are positively charged in the title compound. The oxygen and nitrogen atoms have more negative charges whereas all the hydrogen atoms have the positive charges. The more positive charge

\section{Volume 6 Issue 1, January 2017}




\section{International Journal of Science and Research (IJSR) \\ ISSN (Online): 2319-7064}

Index Copernicus Value (2015): 78.96 | Impact Factor (2015): 6.391

of carbon is found for the title compounds are $\mathrm{C} 2, \mathrm{C} 4, \mathrm{C} 6$ and $\mathrm{C} 7$; it is mainly due to the substitution of negative charge of oxygen and nitrogen atoms. Illustration of atomic charge plotted for B3LYP/ cc-pVDZ and cc-pVTZ levels have been shown in Fig.5.

\section{Frontier Molecular Orbital's Analysis}

Highest Occupied Molecular Orbital (HOMO) and Lowest Unoccupied Molecular Orbital (LUMO) are very important parameters for quantum chemistry. The energies of HOMO, LUMO and their orbital energies are calculated using B3LYP/ cc-pVDZ and cc-pVTZ method and the pictorial illustration of the frontier molecular orbitals are shown in Fig. 6. Molecular orbitals provide insight into the nature of reactivity and some of the structural and physical properties of molecules. The positive and negative phase is represented in red and green colour, respectively. The plots reveal that the region of HOMO spread over the entire molecule of APE while in the case of LUMO it is spread over the entire molecule except on acetyl group. The calculated energy gap of HOMO-LUMO's explains the ultimate charge transfer interface within the molecule. The frontier orbital energy gap (LUMO-HOMO) is calculated by B3LYP/ cc-pVDZ and cc-pVTZ method, in case of APE is found to be 4.7515 , $4.7589 \mathrm{eV}$

\section{Quantum Chemical Parameters}

The quantum chemical parameters are predicted with the HOMO and LUMO orbital energy. Associated within the framework of SCF MO theory, the ionization energy and electron affinity can be expressed through HOMO and LUMO orbital energies as $\mathrm{I}=-\mathrm{E}_{\mathrm{HOMO}}$ and $\mathrm{A}=-\mathrm{E}_{\mathrm{LUMO}}$. The hardness corresponds to the gap between the HOMO and LUMO orbital energies. The larger the HOMO-LUMO energy gaps the harder the molecule. The global hardness is predicted using the relation $\eta=1 / 2\left(\mathrm{E}_{\mathrm{LUMO}}-\mathrm{E}_{\mathrm{HOMO}}\right)$. The hardness has been associated with the stability of chemical system. The reciprocal of the hardness will give the softness $\sigma=(1 / \eta)$ of chemical system. The electron affinity can be used in combination with ionization energy to give electronic chemical potential, $\mu=1 / 2\left(\mathrm{E}_{\mathrm{LUMO}}+\mathrm{E}_{\mathrm{HOMO}}\right)$. The global electrophilicity index is $\omega=\mu^{2} / 2 \eta$ also calculated and presented in Table 8.

\section{Magnetic Susceptibility}

Atoms, molecules, free radicals or ions which contain one or more unpaired electron will possess permanent magnetic dipole moment that arises from the residual spin and angular moment of the unpaired electrons. All substances having permanent magnetic moment display paramagnetic behavior in nature. When a paramagnetic substance is placed in a magnetic field, they will align themselves in the direction of the field and thus produces positive magnetic susceptibility, which depends on the temperature; since thermal agitation will oppose the alignment of the magnetic dipoles. The effectiveness of diminishes increases with increase in temperature. The magnetic susceptibility $\left(\chi_{\mathrm{m}}\right)$ of the molecules for various temperatures are predicted with knowledge of unpaired electron [39] and presented in Table
9. The graphical representation of $\left(1 / \chi_{\mathrm{m}}\right)$ with $\mathrm{T}$ (temperature) is shown in Fig 7. The effective magnetic moment is found to be a constant, which is $5.92 \times 10^{-6}(\mathrm{BM})$ and Curie constant is obtained from the magnetic moment $\left(\mu_{\mathrm{m}}\right)$ and is found to be 0.00083 .

\section{NMR spectral studies}

NMR spectroscopy has proved to be an exceptional tool to elucidate structure and molecular conformation. Density functional theory (DFT) shielding calculations are rapid and applicable to large systems. The "gauge independent atomic orbital" (GIAO) method [40-43] has proven to be quite accepted and accurate. To provide an explicit assignment and analysis of ${ }^{13} \mathrm{C}$ and ${ }^{1} \mathrm{H}$ NMR spectra, theoretical calculations on chemical shift of the title compound are carried out by GIAO method at B3LYP/ cc-pVDZ and ccpVTZ level [44] with $\mathrm{CDCl} 3$ solvent. The ${ }^{1} \mathrm{H}$ and ${ }^{13} \mathrm{C}$ theoretical and experimental chemical shifts, isotropic shielding tensors and the chemical shift assignments are presented in Table 10. The hydrogen atoms are mostly localized on periphery of the molecules and their chemical shifts would be more susceptible to intermolecular interactions as compared to that for other heavier atoms. Unsaturated carbons give signals in overlapped areas of the spectrum with chemical shift values from 100 to $200 \mathrm{ppm}$ [45]. ${ }^{13} \mathrm{C}$ NMR spectra exhibit signals somewhat downfield of $200 \mathrm{ppm}$ depending on the structure. Such signals are typically weak due to the absence of nuclear Overhauser effects. The external magnetic field experienced by the carbon nuclei is affected by the electronegativity of the atoms attached to them. The effect of this is that the chemical shift of the carbon increases if the carbon is attached to an Thus, the carbonyl carbon atom C7 in APE show very downfield effect and the corresponding observed chemical shift is $195.55 \mathrm{ppm}$. The more electronegative character of the oxygen atoms renders a positive charge to the carbon and thus $\mathrm{C} 1$ chemical shift is observed in the more downfield shift at $151.29 \mathrm{ppm}$. The chemical shift values of other carbon atoms of APE are observed at $130.81,127.75$ and $113.70 \mathrm{ppm}$ and are attributed to $\mathrm{C} 4, \mathrm{C} 2$ and $\mathrm{C} 6$, respectively. The methyl carbon atom (C9) connected to the O8 oxygen atom of APE give signal in the upfield chemical shift at $26.07 \mathrm{ppm}$. The ${ }^{1} \mathrm{H}$ chemical shifts of APE are obtained by complete analysis of their NMR spectra and interpreted critically in an attempt to quantify the possible different effects acting on the shielding constant and in turn to the chemical shift of protons. The hydrogen atom $\mathrm{H} 13, \mathrm{H} 14, \mathrm{H} 18$ and $\mathrm{H} 19$ attached with the aromatic carbons of APE shows three peaks at 7.80, 6.64and 6.63 and $7.78 \mathrm{ppm}$, respectively. The hydrogen atom H19, $\mathrm{H} 20$ and H21 attached with the methyl carbon of APE are in the same chemical environment and shows one peak at $2.49 \mathrm{ppm}$. The experimental ${ }^{1} \mathrm{H}$ and ${ }^{13} \mathrm{C}$ NMR chemical shifts are represented in the Fig. 8

\section{Fukui Function}

Fukui indices are, in short, reactivity indices, they give us information about which atoms in a molecule have a larger tendency to either loose or accept an electron, which we chemist interpret as which are more prone to undergo a 


\section{International Journal of Science and Research (IJSR) \\ ISSN (Online): 2319-7064}

Index Copernicus Value (2015): 78.96 | Impact Factor (2015): 6.391

nuclophilic or an electrophilic attack, respectively. The fukui function is defined by R.G Parr [46] as $\quad F(r)=(\delta \rho(r) / \delta$ $(\mathrm{N})) r$

Where $\delta(r)$ is the electronic density, $\mathrm{N}$ is the number of electrons and $r$ is the external potential exerted by the nuclease. fukui function(FF) is the one of the widely used local density functional descriptors to model chemical reactivity and selectivity. The fukui function is a local reactivity descriptors that indicates the preferred where a chemical species will change its density when the number of electron is modified. Therefore, it indicates the propensity of the electronic density to perform at a given position upon accepting or donating electron [47-48]. Also, it is possible to define the corresponding condensed or atomic Fukui functions on the $\mathrm{j}^{\text {th }}$ atom site as,

$$
\begin{aligned}
& F_{j}^{+}=q_{j}(N+1)-q_{j}(N) \\
& F_{j}^{-}=q_{j}(N)-q_{j}(N-1) \\
& F_{j}^{0}=1 / 2\left[q_{j}(N+1)-q_{j}(N-1)\right]
\end{aligned}
$$

Where $f^{k}$ and $f_{j}{ }_{j}$ describe the ability of an atom to accommodate an extra electron or to cope with lose of an electron and $f_{j}^{o}$ is then considered as an indicator for radical reactivity on the reference molecule. In these equation, $q_{j}$ is the atomic charge (evaluated from mulliken population, electrostatic derived charges, etc) at the $\mathrm{j}^{\text {th }}$ atomic site is the neutral $(\mathrm{N})$, anionic $(\mathrm{N}+1)$ or cationic (N-1)chemical species. P.K Chattaraj [49] have introduced the concept of generalized philicity. It contains almost all information about hitherto known different global and local reactivity and selectivity descriptor, in addition to the information regarding electrophilic / nucleophilic power of a given atomic site in a molecule. Morel c et al., [50] have recently proposed a dual descriptor $(\Delta \mathrm{f}(\mathrm{r}))$, which is defined as the difference between the nucleophilic and electrophilic fukui fuction and is given by the equation,

$$
\Delta \mathrm{f}(\mathrm{r})=\left[\mathrm{f}^{+}(\mathrm{r})-\mathrm{f}^{-}(\mathrm{r})\right]
$$

$\Delta \mathrm{f}(\mathrm{r})>0$, then the site is favored for a nucleophilic attack, whereas if $\Delta \mathrm{f}(\mathrm{r})<0$, then the site may be favored for an electrophilic attack. According to dual descriptor $\Delta \mathrm{f}(\mathrm{r})$ provide a clear difference between nucleophilic and electrophilic attack at a particular site with their sign. That is they provide positive value for sited prone for nucliophilic attack and a negative value prone for electrophilic attack. From the values reported in Table.11. according to the condition for dual descriptor, nucleophilic sit for in our title molecule is $\mathrm{C} 1, \mathrm{C} 5, \mathrm{O} 8, \mathrm{C} 9, \mathrm{H} 11, \mathrm{H} 13, \mathrm{~N} 15$ (positive value i.e. $\Delta \mathrm{f}(\mathrm{r})>0$ ). Similarly the electrophilic site is $\mathrm{C} 2, \mathrm{C} 4, \mathrm{C} 6$, C7, H10, H12, H14, H16, H17, H18, H18 (Negative i.e. $\Delta$ f $(\mathrm{r})<0)$. The behavior of molecule as electrophilic and nucliophilic attack during reaction depends on the local behavior of molecule.

\section{Thermodynamic Properties}

For the title compound, the standard thermodynamic functions: heat capacity $\left(\mathrm{C}_{\mathrm{p}: \mathrm{m}}^{0}\right)$, entropy $\left(\mathrm{S}_{\mathrm{m}}^{0}\right)$ and enthalpy $\left(\mathrm{H}^{0} \mathrm{~m}\right)$, Gibb's free energy $\left(\mathrm{G}_{\mathrm{m}}^{0}\right)$ were calculated based on the vibrational analysis by B3LYP method with cc-pVDZ and cc-pVTZ basis sets and statistical thermodynamics were obtained and listed in Table 12. It is noted from Table 12 that the standard heat capacities, entropies and enthalpies increase from 10 to $200 \mathrm{~K}$, because the intensities of molecular vibration increase with the increasing temperature. According to the data in Table 12 for the title compound, the corresponding relations between the thermodynamic properties heat capacity, entropies, enthalpies and temperature are described and shown in fig.9.

\section{Conclusions}

The FT-IR, FT-Raman and NMR spectral studies and quantum chemical parameters, magnetic susceptibility of APE were carried out for the first time. Complete vibrational and molecular structure analyses have been performed based on the quantum mechanical approach by DFT calculations. The differences between the observed and scaled wavenumber values of the most of the fundamentals are very small. Therefore, the assignments made at DFT levels of theory with only reasonable deviations from the experimental values seem to be correct. The NBO result reflects the charge transfer mainly due to $\mathrm{NH}_{2}$ and $\mathrm{CH}_{3}$ groups. The dipole moment, polarizability and first order hyperpolarizabilities reveal that APE behave as interesting NLO materials. The lowering of HOMO-LUMO band gap supports bioactive property of the molecule. Furthermore, information about the size, shape, charge density distribution and site of chemical reactivity of the molecule has been obtained by mapping electron density isosurface with MESP and Fukui fuctions. Therefore, the results presented in this work for APE molecule indicates that these level of theory are reliable for prediction of both infrared and Raman spectra of the title molecule.

\section{Acknowledgement}

The authors acknowledge SAIF-IIT Madras, Chennai for spectral measurement and one of the authors M.Karunanidhi acknowledges the UGC, Ministry of HRD, Govt. of India, for assistance in the form of Minor Research Project.[UGC-SERONO.F.MRP-6116/15].

\section{References}

[1] M. Sittig, Handbook of Toxic and Hazardous Chemicals and Carcinogens, second ed., Noyes Publications, Park Ridge, NJ, 1985.

[2] R. Stewart, K. Yates, J. Am. Chem. Soc. 80 (1958) 6355.

[3] S. Forsen, B. Akermark, T. Alm, Acta Chem. Scand. 18 (1964) 2313-2328nt,

[4] Fu, H.B.;Yao, J.N.Size Effects on the optical properties of Organic Nanoparticles. J.Am. Chem. Soc.2001, 123, 1434- 1439

[5] M.K. Subramanian, P.M. Anbarasan, V. Ilangovan, S. Moorthy Babu, Spectrochim.Acta A 71 (2008) 59-67.

[6] S.K. Seth, D.K. Hazra, Monika Mukherjee, Tanusree Kar, J. Mol. Struct. 936 (2009)277-282.

[7] K. Pei, Y. Ma, X. Zheng, H. Li, Chem. Phys. Lett. 437 (2007) 153-158.

[8] M. Frisch, G.W. Trucks, H.B. Schlegal, G.E. Scuseria, M.A. Robb, J.R. Cheesman,V.G. Zakrzewski, J.A. Montgomerg, Jr., R.E. Strtmann, J.C. Burant, S. Dapprich, J.M.Milliam, A.D. Daniels, K.N. Kudin, M.C. Strain, O. Farkas, J. Tomasi, V. Barone,M. Cossi, R. Camme, B. Mennucci, C. Pomelli, C. Adamo, S. Clifford, J. Ochterski,G.A. Petersson, P.Y. Ayala, Q. 


\section{International Journal of Science and Research (IJSR) ISSN (Online): 2319-7064 \\ Index Copernicus Value (2015): 78.96 | Impact Factor (2015): 6.391}

Cui, K. Morokuma, N. Rega, P. Salvador, J.J.Dannenberg, D.K. Malich, A.D. Rabuck, K. Raghavachari, J.B. Foresman, J.Cioslowski, J.V. Ortiz, A.G. Baboul, B.B. Stetanov, G. Liu, A. Liashenko, P. Piskorz,I. Komaromi, R. Gomperts, R.L. Martin, D.J. Fox, T. Keith, M.A. Al-Laham, C.Y.Peng, A. Nsnsyskkara, M. Challacombe, P.M.W. Gill, B. Johnson, W. Chen, M.W.Wong, J.L. Andres, C. Gonzalez, M. Head-Gordon, E.S. Replogle, J.A. Pople,GAUSSIAN 09, Revision A.02, Gaussian, Inc, Pittsburgh, PA, 2009.

[9] A.D. Becke, J. Chem. Phys. 98 (1993) 5648.

[10] C. Lee, W. Yang, R.G. Parr, Phys. Rev. 37 (1998) 785.

[11] T. Sundius, J. Mol. Struct. 218 (1990) 321.

[12] T. Sundius, Vib. Spectrosc. 29 (2002) 89.

[13] M.J. Frisch, A.B. Nielson, A.J. Holder, Gaussview Users Manual, Gaussian Inc.,Pittsburgh, PA, 2000.

[14] P.L. Polavarapu, J. Phys.Chem. 94 (1990) 8106.

[15] G. Keresztury, S. Holly, J. Varga, G.A. Besenyei, Y. Wang, J.R. Durig, Spectrochim.Acta Part 49A (1993) 2007.

[16] G. Keresztury, Raman Spectroscopy: Theory in: J.M. Chalmers, P.R. Griffiths (Ed.), Hand book of Vibrational Spectroscopy, vol. 1, Wiley, 2002.

[17] G. Ma, B.O. Patrick, T.Q. Hu, B.R. James, Acta Cryst. E59 (2003) o579-o580.

[18] Y. Tanimoto, H. Kobayashi, S. Nagakura, Y. Saito, Acta Crystallogr. B29 (1973)1822-1826. (2004) 67-72.

[19]P.C. Chen, W. Lo, S.C. Tzeng, J. Mol. Struct. (Theochem.) 148 (1998) 257-266.

[20] P.C. Chen, W. Lo, K.H. Hu, Theor. Chem. Acta 95 (1997) 99-112.

[21] P.C. Chen, Y.C. Chieh, J. Mol. Struct. (Theochem.) 583 (2002) 173-180.

[22] G. Varsanyi, Assignments for Vibrational Spectra of Seven Hundred Benzene Derivatives, vol. 1, Adam Hilger, London, 1974.

[23] L.J. Bellamy, The Infrared Spectra of Complex Molecules, third ed., Wiley, NewYork, 1975.

[24] N. Misra, O. Prasad, L. Sinha, A. Pandey, J. Mol. Struct.: (Theochem.) 822 (2007)45-47.

[25] V. Arjunan, S. Thillai Govindaraja, S. Subramanian, S. Mohan, J. Mol. Struct. 1037 (2013) 73-84.

[26]D. Sajan, I. Hubert Joe, V.S. Jayakumar, J. Raman Spectrosc. 37 (2005) 508-519.

[27] P.S. Kalsi, Spectroscopy of Organic Compounds, Wiley Eastern Limited, New Delhi, 1993, pp. 117-118.

[28] A.R. Prabakaran, S. Mohan, Indian J. Phys. 63B (1989) 468-473.

[29] T. Kolev, J. Mol. Struct. 349 (1995) 381-384.
[30]G. Socrates, Infrared, Raman Characteristic Group Frequencies, Tables and Charts, third ed., Wiley, Chichester, 2001.

[31]R.N. Medhi, R. Barman, K.C. Medhi, S.S. Jois, Spectrochim. Acta 56A (2000)1523-1532.

[32] J.S. Murray, K. Sen, Molecular Electrostatic Potentials, Concepts and Applications, Elsevier, Amsterdam, 1996.

[33] I. Fleming, Frontier Orbitals and Organic Chemical Reactions, John Wiley andSons, New York, 1976. pp. $5-27$.

[34] J.M. Seminario, Recent Developments and Applications of Modern Density Functional Theory, vol. 4, Elsevier, 1996. pp. 800-806.

[35] A.E. Reed, F. Weinhold, J. Chem. Phys. 83 (1985) 1736-1740.

[36] A.E. Reed, R.B. Weinstock, F. Weinhold, J. Chem. Phys. 83 (1985) 735-746.

[37] A.E. Reed, F. Weinhold, J. Chem. Phys. 78 (1983) 4066-4073.

[38] J.P. Foster, F. Weinhold, J. Am. Chem. Soc. 102 (1980) 7211-7218.

[39] M.C.Gupta, Atomic and Molecular Spectroscopy, New Age International Private Limited, Publishers, New Delhi, 2001.

[40] P.V.R. Schleyer, N.L. Allinger, T. Clark, J. Gasteiger, P.A. Kolmann, H.F. Schaefer, P.R. Schreiner, The Encyclopedia of Computational Chemistry, John Wiley \&Sons, Chichester, 1998.

[41]R. Ditchfield, Mol. Phys. 27 (1974) 789-807.

[42] M. Barfiled, P. Fagerness, J. Am. Chem. Soc. 119 (1977) 8699-8711.

[43] J.M. Manaj, D. Maciewska, I. Waver, Magn. Reson. Chem. 38 (2000) 482- 485.

[44] A.J.D. Melinda, Solid State NMR Spectroscopy; Principles and Applications, Cambridge Press, 2003.

[45]R.M. Silverstein, F.X. Webster, Spectrometric Identification of Organic Compounds, sixth ed., John Wiley \& Sons, Chichester, 2004.

[46]R.G.Parr, W.Yang, Densitynfunctional Theory of Atoms and Molecules, Oxford University Press, New York, 1989.

[47] P.W.Ayers, R.G.Parr, j. Am. Chem. Soc, 122 (2000) 2010-2018.

[48] R.G.Parr, W.Yang, j. Am. Chem. Soc, 106 (1984) 511516.

[49] P.K.Chattaraj, B.Maiti, U.Sarkar, j. Phys. Chem. A 107(2003) 4973-4975.

[50] C.Morell, A.Grand, A.Toro-Labbe, J.Phys.Chem. A (2005)205-212

Table 1: Optimized structural parameters of 1(4-Aminophenyl)ethanone utilizing B3LYP/cc-pVDZ and B3LYP/cc-pVTZ density functional calculation

\begin{tabular}{|c|c|c|c|c|c|c|c|c|}
\hline \multirow[b]{2}{*}{ Parameters } & \multicolumn{2}{|c|}{ Bond length $\left(\mathrm{A}^{0}\right)$} & \multirow[b]{2}{*}{ Parameters } & \multicolumn{2}{|c|}{ Bond angle $\left(\mathrm{A}^{\circ}\right)$} & \multirow[b]{2}{*}{ Parameters } & \multicolumn{2}{|c|}{ Dihedral angle $\left(\mathrm{A}^{\circ}\right)$} \\
\hline & B3LYP/ cc-pVDZ & $\begin{array}{l}\text { B3LYP/ } \\
\text { cc-pVTZ }\end{array}$ & & $\begin{array}{c}\text { B3LYP } \\
\text { /cc-pVDZ }\end{array}$ & $\begin{array}{l}\text { B3LYP/ } \\
\text { cc-pVTZ }\end{array}$ & & $\begin{array}{l}\text { B3LYP/ } \\
\text { cc-pVDZ }\end{array}$ & $\begin{array}{l}\text { B3LYP/ } \\
\text { cc-pVTZ }\end{array}$ \\
\hline $\mathrm{C} 1-\mathrm{C} 2$ & 1.407 & 1.399 & $\mathrm{C} 2-\mathrm{C} 1-\mathrm{C} 6$ & 117.74 & 117.82 & $\mathrm{C} 6-\mathrm{C} 1-\mathrm{C} 2-\mathrm{C} 3$ & 0 & 0.02 \\
\hline C1-C6 & 1.409 & 1.401 & $\mathrm{C} 2-\mathrm{C} 1-\mathrm{C} 7$ & 123.67 & 123.28 & C6-C1-C2-H13 & 180 & 179.92 \\
\hline $\mathrm{C} 1-\mathrm{C} 7$ & 1.489 & 1.485 & C6-C1-C7 & 118.59 & 118.90 & $\mathrm{C} 7-\mathrm{C} 1-\mathrm{C} 2-\mathrm{C} 3$ & -180 & -179.90 \\
\hline $\mathrm{C} 2-\mathrm{C} 3$ & 1.390 & 1.383 & $\mathrm{C} 1-\mathrm{C} 2-\mathrm{C} 3$ & 121.39 & 121.33 & $\mathrm{C} 7-\mathrm{C} 1-\mathrm{C} 2-\mathrm{H} 13$ & 0 & 0.01 \\
\hline $\mathrm{C} 2-\mathrm{H} 13$ & 1.092 & 1.081 & $\mathrm{C} 1-\mathrm{C} 2-\mathrm{H} 13$ & 120.27 & 120.22 & $\mathrm{C} 2-\mathrm{C} 1-\mathrm{C} 6-\mathrm{C} 5$ & 0 & 0.02 \\
\hline $\mathrm{C} 3-\mathrm{C} 4$ & 1.413 & 1.402 & C3-C2-H13 & 118.35 & 118.46 & C2-C1-C6-H19 & -180 & -179.91 \\
\hline $\mathrm{C} 3-\mathrm{H} 14$ & 1.093 & 1.083 & $\mathrm{C} 2-\mathrm{C} 3-\mathrm{C} 4$ & 120.55 & 120.50 & $\mathrm{C} 7-\mathrm{C} 1-\mathrm{C} 6-\mathrm{C} 5$ & 180 & 179.94 \\
\hline $\mathrm{C} 4-\mathrm{C} 5$ & 1.415 & 1.405 & C2-C3-H14 & 120.01 & 120.00 & C7-C1-C6- H19 & 0 & 0.01 \\
\hline
\end{tabular}

\section{Volume 6 Issue 1, January 2017}


International Journal of Science and Research (IJSR)

ISSN (Online): 2319-7064

Index Copernicus Value (2015): 78.96 | Impact Factor (2015): 6.391

\begin{tabular}{|c|c|c|c|c|c|c|c|c|}
\hline C4-N15 & 1.370 & 1.381 & C4-C3-H14 & 119.44 & 119.50 & $\mathrm{C} 2-\mathrm{C} 1-\mathrm{C} 7-\mathrm{O} 8$ & 180 & 179.72 \\
\hline C5-C6 & 1.385 & 1.378 & C3-C4-C5 & 118.26 & 118.43 & C2-C1-C7-C9 & 0 & -0.30 \\
\hline C5-H18 & 1.094 & 1.083 & C3-C4-N15 & 120.94 & 120.85 & C6-C1-C7-O8 & 0 & -0.20 \\
\hline C6-H19 & 1.091 & 1.081 & C5-C4-N15 & 120.80 & 120.67 & C6-C1-C7-C9 & 180 & 179.79 \\
\hline C7-O8 & 1.224 & 1.218 & C4-C5-C6 & 120.50 & 120.53 & C1-C2-C3-C4 & 0 & -0.01 \\
\hline C7-C9 & 1.522 & 1.518 & C4-C5-H18 & 119.35 & 119.38 & C1-C2-C3-H14 & -180 & -179.78 \\
\hline $\mathrm{C} 9-\mathrm{H} 10$ & 1.103 & 1.092 & C6-C5-H18 & 120.15 & 120.09 & H13-C2-C3-C4 & -180 & -179.92 \\
\hline C9-H11 & 1.103 & 1.092 & C1-C6-C5 & 121.56 & 121.39 & H13-C2-C3-H14 & 0 & 0.31 \\
\hline C9-H12 & 1.097 & 1.086 & C1-C6-H19 & 117.77 & 118.05 & $\mathrm{C} 2-\mathrm{C} 3-\mathrm{C} 4-\mathrm{C} 5$ & 0 & -0.04 \\
\hline N15-H16 & 1.009 & 1.006 & C5-C6-H19 & 120.67 & 120.56 & C2-C3-C4-N15 & -180 & -177.50 \\
\hline \multirow{20}{*}{ N15-H17 } & 1.009 & 1.006 & $\mathrm{C} 1-\mathrm{C} 7-\mathrm{O} 8$ & 121.09 & 121.17 & H14-C3-C4-C5 & 180 & 179.74 \\
\hline & & & C1-C7-C9 & 118.75 & 118.84 & H14-C3-C4-N15 & 0 & 2.27 \\
\hline & & & O8-C7-C9 & 120.16 & 119.99 & C3-C4-C5-C6 & 0 & 0.07 \\
\hline & & & C7-C9-H10 & 111.07 & 111.09 & C3-C4-C5-H18 & -180 & -179.76 \\
\hline & & & C7-C9-H11 & 111.07 & 111.11 & N15-C4-C5-C6 & 180 & 177.54 \\
\hline & & & C7-C9-H12 & 108.69 & 108.58 & N15-C4-C5-H18 & 0 & -2.29 \\
\hline & & & H10-C9-H11 & 107.26 & 107.38 & C3-C4-N15-H16 & 0 & -21.60 \\
\hline & & & H10-C9-H12 & 109.37 & 109.33 & C3-C4-N15-H17 & -180 & -161.19 \\
\hline & & & H11-C9-H12 & 109.37 & 109.33 & C5-C4-N15-H16 & 180 & 161.00 \\
\hline & & & C4-N15-H16 & 121.01 & 116.97 & C5-C4-N15-H17 & 0 & 21.41 \\
\hline & & & C4-N15-H17 & 120.88 & 116.86 & C4-C5-C6-C1 & 0 & -0.07 \\
\hline & & & H16-N15-H17 & 118.11 & 113.61 & C4-C5-C6-H19 & 180 & 179.86 \\
\hline & & & & & & H18-C5-C6-C1 & 180 & 179.76 \\
\hline & & & & & & H18-C5-C6-H19 & 0 & -0.31 \\
\hline & & & & & & C1-C7-C9-H10 & -60 & -59.67 \\
\hline & & & & & & C1-C7-C9-H11 & 60 & 59.80 \\
\hline & & & & & & C1-C7-C9-H12 & -180 & -179.93 \\
\hline & & & & & & O8-C7-C9-H10 & 120 & 120.31 \\
\hline & & & & & & O8-C7-C9-H11 & -120 & -120.21 \\
\hline & & & & & & $\mathrm{O} 8-\mathrm{C} 7-\mathrm{C} 9-\mathrm{H} 12$ & 0 & 0.05 \\
\hline
\end{tabular}

Table 2: Experimental FT-IR, FT-Raman and Calculated DFT-B3LYP/cc-pVDZ, B3LYP/cc-pVTZ levels of vibrational frequencies, IR intensity and Raman intensity of 1(4-Aminophenyl)ethanone

\begin{tabular}{|c|c|c|c|c|c|c|c|c|c|c|c|c|}
\hline \multirow{3}{*}{ No } & \multirow{3}{*}{ Spe. } & \multirow{2}{*}{\multicolumn{2}{|c|}{$\begin{array}{l}\text { Observed } \\
\text { frequencies } \\
\left(\mathrm{cm}^{-1}\right)\end{array}$}} & \multicolumn{4}{|c|}{ Calculated frequencies $\left(\mathrm{cm}^{-1}\right)$} & \multirow{2}{*}{\multicolumn{2}{|c|}{ IR Intensity $\left(\mathrm{kmmol}^{-1}\right)$}} & \multirow{2}{*}{\multicolumn{2}{|c|}{$\begin{array}{l}\text { Raman Intensity } \\
\left(\mathrm{kmmol}^{-1}\right)\end{array}$}} & \multirow{3}{*}{$\begin{array}{c}\text { Vibrational } \\
\text { assignments / PED } \\
(\geq 10 \%)\end{array}$} \\
\hline & & & & \multicolumn{2}{|c|}{$\begin{array}{c}\text { B3LYP/cc- } \\
\text { pVDZ }\end{array}$} & \multicolumn{2}{|c|}{$\begin{array}{c}\text { B3LYP/cc- } \\
\text { pVTZ }\end{array}$} & & & & & \\
\hline & & IR & Raman & Unscaled & Scaled & Unscaled & Scaled & $\begin{array}{c}\text { B3LYP/cc- } \\
\mathrm{pVDZ}\end{array}$ & $\begin{array}{c}\text { B3LYP/cc- } \\
\text { pVTZ }\end{array}$ & $\begin{array}{c}\text { B3LYP/cc- } \\
\mathrm{pVDZ}\end{array}$ & $\begin{array}{c}\text { B3LYP/cc- } \\
\text { pVTZ }\end{array}$ & \\
\hline 1 & $\mathrm{~A}^{\prime}$ & $3395 \mathrm{~s}$ & & 3738 & 3398 & 3680 & 3394 & \begin{tabular}{|l|}
32.2198 \\
\end{tabular} & 19.48 & 4.97 & 7.78 & $v$ ass $\mathrm{NH}_{2}(98)$ \\
\hline 2 & $\mathrm{~A}^{\prime}$ & $3329 \mathrm{vs}$ & $3325 \mathrm{~s}$ & 3610 & 3341 & 3577 & 3330 & 32.220 & 45.22 & 18.88 & 33.26 & $v \operatorname{ss~NH}_{2}(96)$ \\
\hline 3 & $\mathrm{~A}^{\prime}$ & $3086 \mathrm{~m}$ & & 3209 & 3089 & 3199 & 3084 & 100.672 & 3.52 & 9.19 & 14.53 & $v \mathrm{CH}(96)$ \\
\hline 4 & $\mathrm{~A}^{\prime}$ & $3063 \mathrm{~m}$ & $3065 \mathrm{~s}$ & 3196 & 3076 & 3190 & 3063 & 3.352 & 9.06 & 10.11 & 14.81 & $v \mathrm{CH}(98)$ \\
\hline 5 & $\mathrm{~A}^{\prime}$ & & $3046 \mathrm{~m}$ & 3165 & 3048 & 3160 & 3045 & 10.549 & 19.22 & 11.23 & 16.15 & $v \mathrm{CH}(97)$ \\
\hline 6 & $\mathrm{~A}^{\prime}$ & & $3025 \mathrm{w}$ & 3165 & 3036 & 3160 & 3026 & 23.073 & 11.83 & 10.82 & 16.18 & $v \mathrm{CH}(98)$ \\
\hline 7 & $\mathrm{~A}^{\prime}$ & & $2975 \mathrm{w}$ & 3152 & 2975 & 3141 & 2973 & 13.511 & 14.22 & 11.50 & 17.01 & $v_{\text {ass }} \mathrm{CH}_{3}(98)$ \\
\hline 8 & $\mathrm{~A}^{\prime}$ & $2842 \mathrm{vw}$ & & 3103 & 2843 & 3089 & 2840 & 13.848 & 9.85 & 5.86 & 8.30 & $v \operatorname{assCH}_{3}(97)$ \\
\hline 9 & A' & $2819 w$ & & 3035 & 2824 & 3035 & 2820 & 10.267 & 3.84 & 17.78 & 30.41 & $\operatorname{vssCH}_{3}(96)$ \\
\hline 10 & $\mathrm{~A}^{\prime}$ & $1647 \mathrm{~s}$ & $1650 \mathrm{vs}$ & 1753 & 1659 & 1737 & 1653 & 3.836 & 183.23 & 36.52 & 60.99 & $v \mathrm{CO}(76), \delta \mathrm{CC}(18)$ \\
\hline 11 & $\mathrm{~A}^{\prime}$ & & $1612 \mathrm{w}$ & 1665 & 1618 & 1662 & 1610 & 171.873 & 284.33 & 100.00 & 81.90 & $v \mathrm{CC}(71), \delta \mathrm{CH}(19)$ \\
\hline 12 & A" & & $1594 \mathrm{vs}$ & 1625 & 1604 & 1646 & 1593 & 502.076 & 136.94 & 0.17 & 100.00 & $\rho \mathrm{NH}_{2}(88)$ \\
\hline 13 & $\mathrm{~A}^{\prime}$ & $1565 \mathrm{~m}$ & $1564 \mathrm{vs}$ & 1608 & 1589 & 1607 & 1561 & 51.669 & 22.61 & 2.85 & 5.86 & $v \mathrm{CC}(76), \delta \mathrm{CH}(18)$ \\
\hline 14 & $\mathrm{~A}^{\prime}$ & $1514 \mathrm{~m}$ & $1516 \mathrm{~s}$ & 1548 & 1520 & 1551 & 1515 & 18.177 & 13.23 & 16.22 & 15.52 & $\delta \mathrm{CH}(78), v \mathrm{CN}(12)$ \\
\hline 15 & $\mathrm{~A}^{\prime}$ & $1437 \mathrm{vs}$ & $1441 \mathrm{~m}$ & 1473 & 1448 & 1484 & 1440 & 6.765 & 8.82 & 2.36 & 8.79 & $\delta \mathrm{CH}(76), v \mathrm{CC}(18)$ \\
\hline 16 & $\mathrm{~A}^{\prime}$ & & $1386 \mathrm{w}$ & 1452 & 1389 & 1474 & 1382 & 19.907 & 15.74 & 11.80 & 5.15 & $\delta \mathrm{ad} \mathrm{CH}(94)$ \\
\hline 17 & $\mathrm{~A}^{\prime}$ & & $1375 \mathrm{w}$ & 1441 & 1378 & 1473 & 1374 & 7.383 & 16.57 & 5.15 & 4.80 & $\delta$ ad $\mathrm{CH}_{3}(93)$ \\
\hline 18 & $A^{\prime}$ & $1360 \mathrm{vs}$ & & 1376 & 1370 & 1389 & 1362 & 8.339 & 56.71 & 2.85 & 1.42 & $\begin{array}{c}v \mathrm{CC}(66), \delta \mathrm{CN}(16), \\
\delta \mathrm{adCH} 3(10)\end{array}$ \\
\hline 19 & $\mathrm{~A}^{\prime}$ & $1304 \mathrm{~m}$ & $1305 \mathrm{~m}$ & 1369 & 1312 & 1366 & 1302 & 40.611 & 1.14 & 1.63 & 0.93 & $\delta$ sd $\mathrm{CH}_{3}(88)$ \\
\hline 20 & $A^{\prime}$ & & & 1349 & 1299 & 1339 & 1293 & 93.351 & 14.04 & 4.54 & 3.40 & $\begin{array}{c}v \mathrm{CN}(68), \delta \mathrm{CH}(20), \\
v \mathrm{CN}(10),\end{array}$ \\
\hline 21 & $\mathrm{~A}^{\prime}$ & & $1277 \mathrm{vs}$ & 1318 & 1280 & 1325 & 1275 & 85.273 & 65.83 & 2.12 & 7.01 & $\delta \mathrm{CH}(76), v \mathrm{CC}(12)$ \\
\hline 22 & $A^{\prime}$ & & & 1295 & 1199 & 1290 & 1192 & 4.107 & 261.19 & 32.88 & 62.20 & $\begin{array}{c}v \mathrm{CC}(72), \delta \mathrm{CH}(21), \delta \mathrm{sd} \\
\mathrm{CH}_{3}(12)\end{array}$ \\
\hline 23 & $\mathrm{~A}^{\prime}$ & $1173 \mathrm{~s}$ & $1171 \mathrm{~s}$ & 1189 & 1177 & 1203 & 1170 & 219.709 & 108.85 & 6.53 & 18.49 & $\delta \mathrm{CH}(88)$ \\
\hline 24 & $\mathrm{~A}^{\prime}$ & $1134 \mathrm{~s}$ & & 1138 & 1343 & 1156 & 1335 & 96.943 & 9.81 & 1.10 & 1.63 & $\delta \mathrm{CH}(85)$ \\
\hline 25 & A" & $1073 \mathrm{w}$ & $1073 \mathrm{~s}$ & 1088 & 1079 & 1093 & 1074 & 15.399 & 2.99 & 23.92 & 53.32 & $\sigma \operatorname{ar} \mathrm{CH}_{3}(82), \delta \operatorname{sing}(12)$ \\
\hline
\end{tabular}

Volume 6 Issue 1, January 2017

www.ijsr.net

Licensed Under Creative Commons Attribution CC BY 


\section{International Journal of Science and Research (IJSR) ISSN (Online): 2319-7064}

Index Copernicus Value (2015): 78.96 | Impact Factor (2015): 6.391

\begin{tabular}{|c|c|c|c|c|c|c|c|c|c|c|c|c|}
\hline 26 & $\mathrm{~A}^{\prime}$ & $1028 \mathrm{w}$ & $1035 \mathrm{w}$ & 1040 & 1038 & 1076 & 1029 & 1.480 & 1.48 & 0.28 & 1.98 & $\sigma \mathrm{sr} \mathrm{CH}_{3}(89)$ \\
\hline 27 & $\mathrm{~A}^{\prime}$ & & $1003 w$ & 1036 & 1009 & 1049 & 1004 & 1.314 & 0.61 & 1.25 & 0.05 & $\sigma \mathrm{NH}_{2}(78)$ \\
\hline 28 & A" & $958 \mathrm{vs}$ & $960 \mathrm{~m}$ & 1015 & 975 & 1028 & 962 & 0.436 & 0.30 & 2.33 & 2.51 & Sring $(71)$ \\
\hline 29 & A" & & $943 w$ & 1000 & 958 & 1004 & 945 & 0.714 & 0.71 & 0.83 & 0.41 & $\gamma \mathrm{CH}(66), \sigma a r \mathrm{CH}_{3}(27)$ \\
\hline 30 & A" & & $901 \mathrm{w}$ & 961 & 909 & 967 & 900 & 0.774 & 0.32 & 1.08 & 0.55 & $\gamma \mathrm{CH}(73)$ \\
\hline 31 & $\mathrm{~A}^{\prime \prime}$ & $839 \mathrm{vs}$ & $842 \mathrm{~s}$ & 953 & 851 & 956 & 945 & 0.363 & 49.04 & 15.19 & 21.46 & $v \mathrm{CH}_{3}(70), \sigma \mathrm{sr} \mathrm{CH}_{3}(17)$ \\
\hline 32 & $\mathrm{~A}^{\prime}$ & & $823 m$ & 850 & 835 & 853 & 820 & 44.009 & 36.45 & 55.66 & 19.29 & \begin{tabular}{|c|} 
Sring $(70)$ \\
\end{tabular} \\
\hline 33 & A" & & $811 \mathrm{w}$ & 844 & 827 & 846 & 812 & 2.456 & 9.53 & 2.26 & 74.23 & $\gamma \mathrm{CH}(71), \delta \mathrm{ad} \mathrm{CH}_{3}(12)$ \\
\hline 34 & A" & & $785 \mathrm{w}$ & 819 & 793 & 826 & 783 & 26.705 & 8.15 & 6.80 & 2.15 & $\gamma \mathrm{CH}(82)$ \\
\hline 35 & A" & & $733 w$ & 754 & 746 & 752 & 730 & 4.931 & 0.77 & 0.00 & 0.91 & $\gamma \operatorname{ring}(78), \gamma \mathrm{CC}(10)$ \\
\hline 36 & $\mathrm{~A}^{\prime}$ & $697 \mathrm{~s}$ & $689 \mathrm{~m}$ & 699 & 706 & 698 & 695 & 0.075 & 2.25 & 8.81 & 12.12 & $\delta \mathrm{CO}(68), \delta \mathrm{CC}(18)$ \\
\hline 37 & A" & & $636 \mathrm{~m}$ & 648 & 649 & 654 & 637 & 0.537 & 1.02 & 13.45 & 20.15 & $\gamma \operatorname{ring}(67)$ \\
\hline 38 & $A^{\prime \prime}$ & $596 \mathrm{~s}$ & & 605 & 603 & 602 & 591 & 1.127 & 11.78 & 1.59 & 1.28 & $\begin{array}{c}\gamma \mathrm{CO}(55), \gamma \mathrm{CC}(18), \gamma \mathrm{CH}( \\
10)\end{array}$ \\
\hline 39 & $A^{\prime}$ & $560 \mathrm{~s}$ & $564 \mathrm{~m}$ & 576 & 569 & 579 & 560 & 12.055 & 15.53 & 4.64 & 8.14 & $\delta$ ring $(62), \delta \mathrm{CO}(21)$ \\
\hline 40 & A" & & $496 w$ & 510 & 508 & 517 & 495 & 30.740 & 73.93 & 0.59 & 19.22 & $\begin{array}{c}\gamma \\
\operatorname{ring}(57), \gamma \mathrm{CN}(12), \gamma \mathrm{CO}( \\
10) \\
\end{array}$ \\
\hline 41 & $A^{\prime}$ & & $436 w$ & 469 & 443 & 476 & 435 & 9.469 & 239.24 & 5.70 & 63.90 & $v \mathrm{CC}(70), \delta \mathrm{CH}(21)$ \\
\hline 42 & $A^{\prime}$ & & $405 w$ & 427 & 419 & 469 & 408 & 2.335 & 106.74 & 0.65 & 12.15 & $v \mathrm{CC}(71), \delta \mathrm{CH}(19)$ \\
\hline 43 & $\mathrm{~A}^{\prime}$ & & $388 \mathrm{w}$ & 417 & 401 & 424 & 388 & 0.000 & 0.11 & 3.95 & 0.04 & $\tau \mathrm{NH}_{2}(71)$ \\
\hline 44 & $\mathrm{~A}^{\prime}$ & & $353 \mathrm{~m}$ & 379 & 363 & 385 & 350 & 0.004 & 1.39 & 3.81 & 5.13 & $\delta \mathrm{CN}(68)$ \\
\hline 45 & A" & & $335 \mathrm{w}$ & 340 & 349 & 355 & 332 & 2.361 & 13.70 & 24.84 & 4.22 & $\gamma \operatorname{ring}(61), \gamma \mathrm{CC}(18)$ \\
\hline 46 & $A^{\prime}$ & & $270 w$ & 278 & 282 & 340 & 275 & 0.146 & 0.94 & 6.81 & 32.18 & $\delta \mathrm{CC}(69)$ \\
\hline 47 & A" & & 185 & 193 & 198 & 277 & 188 & 2.051 & 4.29 & 4.73 & 13.00 & $\gamma \mathrm{CC}(52)$ \\
\hline 48 & $\mathrm{~A}^{\prime}$ & & & 167 & 161 & 194 & 145 & 4.058 & 4.59 & 0.30 & 6.47 & $\tau \mathrm{CH}_{3}(75)$ \\
\hline 49 & A" & & $110 \mathrm{~s}$ & 105 & 106 & 149 & 100 & 0.257 & 0.09 & 50.94 & 0.09 & $\gamma \mathrm{CN}(62), \gamma \mathrm{CC}(21)$ \\
\hline 50 & $A^{\prime \prime}$ & & $85 \mathrm{~m}$ & 83 & 89 & 104 & 84 & 0.618 & 0.70 & 101.18 & 58.73 & $\gamma \mathrm{CH}_{3}(60), \gamma \operatorname{ring}(61)$ \\
\hline 51 & $\mathrm{~A}^{\prime}$ & & & 37 & 36 & 73 & 33 & 3.411 & 3.65 & 293.00 & 111.76 & $\delta$ rockNH $2(79)$ \\
\hline
\end{tabular}

$\nu$-stretching, $\delta$-in-plane bending, $\gamma$-out-of-plane bending, $\rho$-scissoring, $\sigma$-rocking, $\tau$-twisting, $\delta$ ring-in-plane bending ring, rring-out-of -plane bending ring .

Table 3: Accumulation of natural charges and electron population of atoms in core, valance, Rydberg orbitals of 1(4Aminophenyl)ethanone

\begin{tabular}{|c|c|c|c|c|c|c|c|c|c|c|c|}
\hline \multirow{2}{*}{ Atoms $^{\mathrm{a}}$} & \multirow{2}{*}{ Charge (e) } & \multicolumn{3}{|c|}{ Natural population (e) } & \multirow{2}{*}{ Total (e) } & \multirow{2}{*}{ Atoms $^{\mathrm{b}}$} & \multirow{2}{*}{ Charge(e) } & \multicolumn{3}{|c|}{ Natural population (e) } & \multirow{2}{*}{ Total (e) } \\
\hline & & Core & Valence & Rydberg & & & & Core & Valence & Rydberg & \\
\hline $\mathrm{C} 4$ & 0.209 & 1.999 & 3.775 & 0.017 & 5.791 & $\mathrm{C} 1$ & -0.187 & 1.999 & 4.171 & 0.017 & 6.187 \\
\hline $\mathrm{C} 7$ & 0.591 & 1.999 & 3.364 & 0.046 & 5.409 & $\mathrm{C} 2$ & -0.184 & 1.999 & 4.172 & 0.013 & 6.184 \\
\hline $\mathrm{H} 10$ & 0.229 & 0.000 & 0.768 & 0.003 & 0.771 & $\mathrm{C} 3$ & -0.270 & 1.999 & 4.256 & 0.014 & 6.270 \\
\hline H11 & 0.229 & 0.000 & 0.768 & 0.003 & 0.771 & $\mathrm{C} 5$ & -0.267 & 1.999 & 4.254 & 0.014 & 6.267 \\
\hline H12 & 0.237 & 0.000 & 0.759 & 0.004 & 0.763 & C6 & -0.158 & 1.999 & 4.142 & 0.017 & 6.158 \\
\hline H13 & 0.226 & 0.000 & 0.772 & 0.003 & 0.774 & $\mathrm{O} 8$ & -0.567 & 2.000 & 6.558 & 0.009 & 8.567 \\
\hline H14 & 0.221 & 0.000 & 0.776 & 0.003 & 0.779 & C9 & -0.716 & 1.999 & 4.709 & 0.008 & 6.716 \\
\hline H16 & 0.393 & 0.000 & 0.603 & 0.004 & 0.607 & N15 & -0.842 & 2.000 & 5.833 & 0.010 & 7.842 \\
\hline $\mathrm{H} 17$ & 0.394 & 0.000 & 0.602 & 0.004 & 0.606 & & & & & & \\
\hline H18 & 0.222 & 0.000 & 0.775 & 0.003 & 0.778 & & & & & & \\
\hline H19 & 0.240 & 0.000 & 0.755 & 0.005 & 0.760 & & & & & & \\
\hline
\end{tabular}

${ }^{\mathrm{a}}$ Atoms containing positive charges ${ }^{\mathrm{b}}$ Atoms containing negative charges

Table 4 : Significant second-order interaction energy (E (2), $\mathrm{kcal} / \mathrm{mol})$ between donor and acceptor orbital of 1(4Aminophenyl) ethanone calculated at B3LYP/cc-pVDZ level of theory.

\begin{tabular}{|c|c|c|c|c|c|c|c|c|c|}
\hline $\begin{array}{l}\text { Donor (i) } \\
\end{array}$ & Acceptor (j) & $\mathrm{E}(2)^{\mathrm{a}} \mathrm{kcal} / \mathrm{mol}$ & $\left(\varepsilon_{i}-\varepsilon_{j}\right)^{\mathrm{b}}$ a.u & $\begin{array}{lll}F_{i j}{ }^{\mathrm{c}} & \text { a.u } \\
\end{array}$ & Donor (i) & Acceptor (j) & $\mathrm{E}(2)^{\mathrm{a}} \mathrm{kcal} / \mathrm{mol}$ & $\left(\varepsilon_{i}-\varepsilon_{j}\right)^{\mathrm{b}}$ a.u & $F_{i j}{ }^{\mathrm{c}} \quad$ a.u \\
\hline$\sigma(\mathrm{C} 1-\mathrm{C} 2)$ & $\sigma^{*}(\mathrm{C} 1-\mathrm{C} 6)$ & 4.29 & 1.3 & 0.067 & $\sigma(\mathrm{C} 4-\mathrm{N} 15)$ & $\sigma^{*}(\mathrm{C} 5-\mathrm{C} 6)$ & 2.06 & 1.34 & 0.047 \\
\hline$\sigma(\mathrm{C} 1-\mathrm{C} 2)$ & $\sigma^{*}(\mathrm{C} 2-\mathrm{C} 3)$ & 3.18 & 1.29 & 0.057 & $\sigma(\mathrm{C} 5-\mathrm{C} 6)$ & $\sigma^{*}(\mathrm{C} 1-\mathrm{C} 6)$ & 3.21 & 1.29 & 0.057 \\
\hline$\sigma(\mathrm{C} 1-\mathrm{C} 2)$ & $\sigma^{*}(\mathrm{C} 3-\mathrm{H} 14)$ & 2.66 & 1.17 & 0.05 & $\sigma(\mathrm{C} 5-\mathrm{C} 6)$ & $\sigma^{*}(\mathrm{C} 1-\mathrm{C} 7)$ & 3.86 & 1.1 & 0.059 \\
\hline$\sigma(\mathrm{C} 1-\mathrm{C} 2)$ & $\sigma^{*}(\mathrm{C} 6-\mathrm{H} 19)$ & 2.48 & 1.19 & 0.049 & $\sigma(\mathrm{C} 5-\mathrm{C} 6)$ & $\sigma^{*}(\mathrm{C} 4$ & 3.18 & 1.28 & 0.057 \\
\hline$\sigma(\mathrm{C} 1-\mathrm{C} 6)$ & $\sigma^{*}(\mathrm{C} 1-\mathrm{C} 2)$ & 4.32 & 1.29 & 0.067 & $\sigma(\mathrm{C} 5-\mathrm{C} 6)$ & $\sigma^{*}(\mathrm{C} 4-\mathrm{N} 15)$ & 4.63 & 1.03 & 0.062 \\
\hline$\sigma(\mathrm{C} 1-\mathrm{C} 6)$ & $\sigma^{*}(\mathrm{C}$ & 2 & 1.1 & 0.042 & $\sigma(\mathrm{C}$ & & 3.9 & 1.13 & 0.059 \\
\hline$\sigma(\mathrm{C} 1-\mathrm{C} 6)$ & $\sigma^{*}(\mathrm{C} 2$ & 2.77 & 1.17 & 0.051 & $\sigma(\mathrm{C} 5-\mathrm{H} 18)$ & $-\mathrm{C} 4)$ & 4.77 & 1.12 & 0.065 \\
\hline$\sigma(\mathrm{C} 1-\mathrm{C} 6)$ & $\sigma^{*}(\mathrm{C} 5-\mathrm{C} 6)$ & 2.79 & 1.29 & 0.054 & $\sigma(\mathrm{C} 6-\mathrm{H} 19)$ & $\sigma^{*}(\mathrm{C} 1-\mathrm{C} 2)$ & 4.97 & 1.12 & 0.067 \\
\hline$\sigma(\mathrm{C} 1-\mathrm{C} 6)$ & $\sigma^{*}(\mathrm{C} 5-\mathrm{H} 18)$ & 2.68 & 1.17 & 0.05 & $\sigma(\mathrm{C} 6-\mathrm{H} 19)$ & $\sigma^{*}(\mathrm{C} 4-\mathrm{C} 5)$ & 4.18 & 1.11 & 0.061 \\
\hline$\sigma(\mathrm{C} 1-\mathrm{C} 7)$ & $\sigma^{*}(\mathrm{C} 1-\mathrm{C} 6)$ & 2 & 1.22 & 0.044 & $\sigma(C 7$ - C9) & $\sigma^{*}(\mathrm{C} 1-\mathrm{C} 6)$ & 2.65 & 1.22 & 0.051 \\
\hline
\end{tabular}

Volume 6 Issue 1, January 2017 


\section{International Journal of Science and Research (IJSR) \\ ISSN (Online): 2319-7064}

Index Copernicus Value (2015): 78.96 | Impact Factor (2015): 6.391

\begin{tabular}{|c|c|c|c|c|c|c|c|c|c|}
\hline$\sigma(\mathrm{C} 1-\mathrm{C} 7)$ & $\sigma^{*}(\mathrm{C} 2-\mathrm{C} 3)$ & 2.79 & 1.22 & 0.052 & $\sigma(\mathrm{C} 9-\mathrm{H} 10)$ & $\sigma^{*}(\mathrm{C} 7-\mathrm{O} 8)$ & 4.26 & 0.54 & 0.044 \\
\hline$\sigma(\mathrm{C} 1-\mathrm{C} 7)$ & $\sigma^{*}(\mathrm{C} 5-\mathrm{C} 6)$ & 2.81 & 1.21 & 0.052 & $\sigma(\mathrm{C} 9-\mathrm{H} 11)$ & $\sigma^{*}(\mathrm{C} 7-\mathrm{O} 8)$ & 4.26 & 0.54 & 0.044 \\
\hline$\sigma(\mathrm{C} 2-\mathrm{C} 3)$ & $\sigma^{*}(\mathrm{C} 1-\mathrm{C} 2)$ & 3.55 & 1.29 & 0.061 & $\sigma(\mathrm{C} 9-\mathrm{H} 12)$ & $\sigma^{*}(\mathrm{C} 1-\mathrm{C} 7)$ & 3.81 & 0.92 & 0.054 \\
\hline$\sigma(\mathrm{C} 2-\mathrm{C} 3)$ & $\sigma^{*}(\mathrm{C} 1-\mathrm{C} 7)$ & 3.88 & 1.11 & 0.059 & $\sigma(\mathrm{N} 15-\mathrm{H} 16)$ & $\sigma^{*}(\mathrm{C} 4-\mathrm{C} 5)$ & 2.94 & 1.26 & 0.054 \\
\hline$\sigma(\mathrm{C} 2-\mathrm{C} 3)$ & $\sigma^{*}(\mathrm{C} 3-\mathrm{C} 4)$ & 3.24 & 1.28 & 0.058 & $\sigma(\mathrm{N} 15-\mathrm{H} 17)$ & $\sigma^{*}(\mathrm{C} 3-\mathrm{C} 4)$ & 2.95 & 1.25 & 0.055 \\
\hline$\sigma(\mathrm{C} 2-\mathrm{C} 3)$ & $\sigma^{*}(\mathrm{C} 4-\mathrm{N} 15)$ & 4.54 & 1.04 & 0.061 & $\mathrm{Lp} \sigma(\mathrm{O} 8)$ & $\sigma^{*}(\mathrm{C} 1-\mathrm{C} 7)$ & 2.24 & 1.08 & 0.044 \\
\hline$\sigma(\mathrm{C} 2-\mathrm{H} 13)$ & $\sigma^{*}(\mathrm{C} 1-\mathrm{C} 6)$ & 4.66 & 1.13 & 0.065 & $\mathrm{Lp} \sigma(\mathrm{N} 15)$ & $\sigma^{*}(\mathrm{C} 3-\mathrm{C} 4)$ & 28.59 & 0.28 & 0.085 \\
\hline$\sigma(\mathrm{C} 2-\mathrm{H} 13)$ & $\sigma^{*}(\mathrm{C} 3-\mathrm{C} 4)$ & 4.03 & 1.12 & 0.06 & $\pi(\mathrm{C} 7-\mathrm{O} 8)$ & $\pi^{*}(\mathrm{C} 1-\mathrm{C} 2)$ & 124.59 & 0.01 & 0.066 \\
\hline$\sigma(\mathrm{C} 3-\mathrm{C} 4)$ & $\sigma^{*}(\mathrm{C} 2-\mathrm{C} 3)$ & 2.98 & 1.31 & 0.056 & $\pi(\mathrm{C} 1-\mathrm{C} 2)$ & $\pi^{*}(\mathrm{C} 3-\mathrm{C} 4)$ & 16.78 & 0.28 & 0.062 \\
\hline$\sigma(\mathrm{C} 3-\mathrm{C} 4)$ & $\sigma^{*}(\mathrm{C} 2-\mathrm{H} 13)$ & 2.51 & 1.19 & 0.049 & $\pi(\mathrm{C} 1-\mathrm{C} 2)$ & $\pi^{*}(\mathrm{C} 5-\mathrm{C} 6)$ & 22.89 & 0.29 & 0.073 \\
\hline$\sigma(\mathrm{C} 3-\mathrm{C} 4)$ & $\sigma^{*}(\mathrm{C} 4-\mathrm{C} 5)$ & 4 & 1.3 & 0.064 & $\pi(\mathrm{C} 1-\mathrm{C} 2)$ & $\pi^{*}(\mathrm{C} 7-\mathrm{O} 8)$ & 17.19 & 0.28 & 0.065 \\
\hline$\sigma(\mathrm{C} 3-\mathrm{C} 4)$ & $\sigma^{*}(\mathrm{C} 5-\mathrm{H} 18)$ & 2.51 & 1.19 & 0.049 & $\pi(\mathrm{C} 3-\mathrm{C} 4)$ & $\pi^{*}(\mathrm{C} 1-\mathrm{C} 2)$ & 24.31 & 0.3 & 0.076 \\
\hline$\sigma(\mathrm{C} 3-\mathrm{H} 14)$ & $\sigma^{*}(\mathrm{C} 1-\mathrm{C} 2)$ & 3.98 & 1.13 & 0.06 & $\pi(\mathrm{C} 3-\mathrm{C} 4)$ & $\pi^{*}(\mathrm{C} 5-\mathrm{C} 5)$ & 15.73 & 0.3 & 0.062 \\
\hline$\sigma(\mathrm{C} 3-\mathrm{H} 14)$ & $\sigma^{*}(\mathrm{C} 4-\mathrm{C} 5)$ & 4.71 & 1.12 & 0.065 & $\pi(\mathrm{C} 5-\mathrm{C} 6)$ & $\pi^{*}(\mathrm{C} 1-\mathrm{C} 2)$ & 17.03 & 0.29 & 0.064 \\
\hline$\sigma(\mathrm{C} 4-\mathrm{C} 5)$ & $\sigma^{*}(\mathrm{C} 3-\mathrm{C} 4)$ & 4 & 1.3 & 0.064 & $\pi(\mathrm{C} 5-\mathrm{C} 6)$ & $\pi^{*}(\mathrm{C} 3-\mathrm{C} 4)$ & 24.69 & 0.28 & 0.076 \\
\hline$\sigma(\mathrm{C} 4-\mathrm{C} 5)$ & $\sigma^{*}(\mathrm{C} 3-\mathrm{H} 14)$ & 2.53 & 1.19 & 0.049 & $\pi(\mathrm{C} 7-\mathrm{O} 8)$ & $\pi^{*}(\mathrm{C} 1-\mathrm{C} 2)$ & 4.13 & 0.4 & 0.04 \\
\hline$\sigma(\mathrm{C} 4-\mathrm{C} 5)$ & $\sigma^{*}(\mathrm{C} 5-\mathrm{C} 6)$ & 2.85 & 1.3 & 0.055 & $\pi(\mathrm{O} 8)$ & $\pi^{*}(\mathrm{C} 1-\mathrm{C} 7)$ & 19.28 & 0.66 & 0.102 \\
\hline$\sigma(\mathrm{C} 4-\mathrm{C} 5)$ & $\sigma^{*}(\mathrm{C} 6-\mathrm{H} 19)$ & 2.29 & 1.21 & 0.047 & $\pi(\mathrm{O} 8)$ & $\pi^{*}(\mathrm{C} 7-\mathrm{C} 9)$ & 20.09 & 0.63 & 0.102 \\
\hline$\sigma(\mathrm{C} 4-\mathrm{N} 15)$ & $\sigma^{*}(\mathrm{C} 2-\mathrm{C} 3)$ & 2.08 & 1.34 & 0.047 & & & & & \\
\hline
\end{tabular}

${ }^{a} \mathrm{E}(2)$ means energy hyper conjugative interactions.

${ }^{\mathrm{b}}$ Energy difference between donor and acceptor $\mathrm{i}$ and $\mathrm{j}$ NBO orbitals.

${ }^{c} \mathrm{~F}(\mathrm{i}, \mathrm{j})$ is the Fock matrix element between $\mathrm{i}$ and $\mathrm{j}$ NBO orbitals.

Table 5: Natural atomic orbital occupancies and energies of most interacting NBO's of 1(4- Aminophenyl)ethanone along with their hybrid atomic orbitals and hybrid directionality.

\begin{tabular}{|c|c|c|c|c|c|c|c|}
\hline Parameters ${ }^{\mathrm{a}}(\mathrm{A}-\mathrm{B})$ & Occupancies & $\mathrm{ED}_{\mathrm{A}} \%$ & $\mathrm{ED}_{\mathrm{B}} \%$ & Energies(a.u)(A,B) & Hybrid & $\mathrm{AO}(\%)^{\mathrm{b}}$ & $\% \mathrm{~d}$ \\
\hline$\sigma(\mathrm{C} 1-\mathrm{C} 2)$ & 1.9735 & $50.41 \%$ & $49.59 \%$ & $0.710,0.704$ & $\mathrm{sp}^{1.85}(\mathrm{C} 1) \mathrm{sp}^{1.82}(\mathrm{C} 2)$ & $\begin{array}{l}\mathrm{s}(35.13 \%)+\mathrm{p}(64.84 \%) \\
\mathrm{s}(35.46 \%)+\mathrm{p}(64.50 \%)\end{array}$ & $\begin{array}{l}0.00(0.03 \%) \\
0.00(0.03 \%)\end{array}$ \\
\hline$\sigma(\mathrm{C} 1-\mathrm{C} 6)$ & 1.9726 & $50.81 \%$ & $49.19 \%$ & $0.712,0.701$ & $\mathrm{sp}^{1.83}(\mathrm{C} 1) \mathrm{sp}^{1.82}(\mathrm{C} 6)$ & $\begin{array}{c}\mathrm{s}(35.33 \%)+\mathrm{p}(64.64 \%) \\
\mathrm{s}(35.48 \%)+\mathrm{p}(64.49 \%\end{array}$ & $\begin{array}{l}0.00(0.03 \%) \\
0.00(0.04 \%)\end{array}$ \\
\hline$\sigma(\mathrm{C} 1-\mathrm{C} 7)$ & 1.9769 & $52.71 \%$ & $47.29 \%$ & $0.726,0.687$ & $\mathrm{sp}^{2.39}(\mathrm{C} 1) \mathrm{sp}^{1.85}(\mathrm{C} 7)$ & $\begin{array}{l}\mathrm{s}(29.52 \%)+\mathrm{p}(70.45 \%) \\
\mathrm{s}(35.03 \%)+\mathrm{p}(64.91 \%)\end{array}$ & $\begin{array}{l}0.00(0.03 \%) \\
0.00(0.05 \%)\end{array}$ \\
\hline$\sigma(\mathrm{C} 2-\mathrm{C} 3)$ & 1.9733 & $49.98 \%$ & $50.02 \%$ & $0.706,0.707$ & $\mathrm{sp}^{1.82}(\mathrm{C} 2) \mathrm{sp}^{1.78}(\mathrm{C} 3)$ & $\begin{array}{l}\mathrm{s}(35.40 \%)+p(64.57 \%) \\
\mathrm{s}(36.02 \%)+p(63.95 \%) \\
\end{array}$ & $\begin{array}{l}0.00(0.03 \%) \\
0.00(0.03 \%) \\
\end{array}$ \\
\hline$\sigma(\mathrm{C} 2-\mathrm{H} 13)$ & 1.9786 & $61.39 \%$ & $38.61 \%$ & $0.783,0.621$ & $\mathrm{sp}^{2.44}(\mathrm{C} 2) \mathrm{sp}^{0.00}(\mathrm{H} 13)$ & $\begin{array}{c}\mathrm{s}(29.04 \%)+\mathrm{p}(70.94 \%) \\
\mathrm{s}(99.90 \%)+\mathrm{p}(0.10 \%)\end{array}$ & $0.00(0.02 \%)$ \\
\hline$\sigma(\mathrm{C} 3-\mathrm{C} 4)$ & 1.9739 & $49.36 \%$ & $50.64 \%$ & $0.702,0.711$ & $\mathrm{sp}^{1.84}(\mathrm{C} 3) \mathrm{sp}^{1.69}(\mathrm{C} 4)$ & $\begin{array}{l}\mathrm{s}(35.15 \%)+\mathrm{p}(64.82 \%) \\
\mathrm{s}(37.13 \%)+\mathrm{p}(62.83 \%)\end{array}$ & $\begin{array}{l}0.00(0.04 \%) \\
0.00(0.03 \%)\end{array}$ \\
\hline$\sigma(\mathrm{C} 3-\mathrm{H} 14)$ & 1.9789 & $61.17 \%$ & $38.83 \%$ & $0.782,0.623$ & $\mathrm{sp}^{2.48}(\mathrm{C} 3) \mathrm{sp}^{0.00}(\mathrm{H} 14)$ & $\begin{array}{c}\mathrm{s}(28.73 \%)+\mathrm{p}(71.25 \%) \\
\mathrm{s}(99.90 \%)+\mathrm{p}(0.10 \%)\end{array}$ & $0.00(0.02 \%)$ \\
\hline$\sigma(\mathrm{C} 4-\mathrm{C} 5)$ & 1.9743 & $50.74 \%$ & $49.26 \%$ & $0.712,0.701$ & $\mathrm{sp}^{1.69}(\mathrm{C} 4) \mathrm{sp}^{1.85}(\mathrm{C} 5)$ & $\begin{array}{l}\mathrm{s}(37.20 \%)+\mathrm{p}(62.7 \\
\mathrm{s}(35.07 \%)+\mathrm{p}(64.8\end{array}$ & $\begin{array}{l}0.00(0.03 \%) \\
0.00(0.04 \%)\end{array}$ \\
\hline$\sigma(\mathrm{C} 4-\mathrm{N} 15)$ & 1.9908 & $39.34 \%$ & $60.66 \%$ & $0.627,0.778$ & $\mathrm{sp}^{2.93}(\mathrm{C} 4) \mathrm{sp}^{1.62}(\mathrm{~N} 15)$ & $\begin{array}{l}\mathrm{s}(25.39 \%)+\mathrm{p}(74.51 \%) \\
\mathrm{s}(38.09 \%)+\mathrm{p}(61.87 \%)\end{array}$ & $\begin{array}{l}0.00(0.10 \%) \\
0.00(0.03 \%)\end{array}$ \\
\hline$\sigma(\mathrm{C} 5-\mathrm{C} 6)$ & 1.9735 & $50.29 \%$ & $49.71 \%$ & $0.709,0.705$ & $\mathrm{sp}^{1.78}(\mathrm{C} 5) \mathrm{sp}^{1.85}(\mathrm{C} 6)$ & $\begin{array}{l}\mathrm{s}(36.01 \%)+\mathrm{p}(63.96 \%) \\
\mathrm{s}(35.07 \%)+\mathrm{p}(64.90 \%)\end{array}$ & $\begin{array}{l}0.00(0.03 \%) \\
0.00(0.03 \%)\end{array}$ \\
\hline$\sigma(\mathrm{C} 5-\mathrm{H} 18)$ & 1.9788 & $61.22 \%$ & $38.78 \%$ & $0.782,0.622$ & $\mathrm{sp}^{2.47}(\mathrm{C} 5) \mathrm{sp}^{0.00}(\mathrm{H} 18)$ & $\begin{array}{c}\mathrm{s}(28.81 \%)+\mathrm{p}(71.18 \%) \\
\mathrm{s}(99.90 \%)+\mathrm{p}(0.10 \%)\end{array}$ & $0.00(0.02 \%)$ \\
\hline$\sigma(\mathrm{C} 6-\mathrm{H} 19)$ & 1.9785 & $62.28 \%$ & $37.72 \%$ & $0.789,0.614$ & $\mathrm{sp}^{2.41}(\mathrm{C} 6) \mathrm{sp}^{0.00}(\mathrm{H} 19)$ & $\begin{array}{c}\mathrm{s}(29.36 \%)+\mathrm{p}(70.63 \%) \\
\mathrm{s}(99.89 \%)+\mathrm{p}(0.11 \%)\end{array}$ & $0.00(0.02 \%)$ \\
\hline$\sigma(\mathrm{C} 7-08)$ & 1.9961 & $33.01 \%$ & $66.99 \%$ & $0.574,0.818$ & $\mathrm{sp}^{2.28}(\mathrm{C} 7) \mathrm{sp}^{1.30}(\mathrm{O} 8)$ & $\begin{array}{l}\mathrm{s}(30.41 \%)+\mathrm{p}(69.38 \%) \\
\mathrm{s}(43.46 \%)+\mathrm{p}(56.46 \%)\end{array}$ & $\begin{array}{l}0.01(0.21 \%) \\
0.00(0.09 \%)\end{array}$ \\
\hline$\sigma(\mathrm{C} 7-\mathrm{C} 9)$ & 1.9886 & $48.24 \%$ & $51.76 \%$ & 0.6945 .719 & $\mathrm{sp}^{1.91}(\mathrm{C} 7) \mathrm{sp}^{2.72}(\mathrm{C} 9)$ & $\begin{array}{l}\mathrm{s}(34.37 \%)+\mathrm{p}(65.58 \%) \\
\mathrm{s}(26.86 \%)+\mathrm{p}(73.09 \%)\end{array}$ & $0.05 \%(0.05 \%)$ \\
\hline$\sigma(\mathrm{C} 9-\mathrm{H} 10)$ & 1.9750 & $61.23 \%$ & $38.77 \%$ & $0.782,0.622$ & $\mathrm{sp}^{3.14}(\mathrm{C} 9)(\mathrm{H} 10)$ & $\begin{array}{c}\mathrm{s}(24.13 \%)+\mathrm{p}(75.85 \%) \\
\mathrm{s}(99.90 \%)+\mathrm{p}(0.10 \%)\end{array}$ & $0.00(0.03 \%)$ \\
\hline$\sigma(\mathrm{C} 9-\mathrm{H} 11)$ & 1.9750 & $61.23 \%$ & $38.77 \%$ & $0.782,0.622$ & $\mathrm{sp}^{3.14}(\mathrm{C} 9) \mathrm{sp}^{0.00}(\mathrm{H} 11)$ & $\begin{array}{c}\mathrm{s}(24.13 \%)+\mathrm{p}(75.85 \%) \\
\mathrm{s}(99.90 \%)+\mathrm{p}(0.10 \%)\end{array}$ & $0.00(0.03 \%)$ \\
\hline$\sigma(\mathrm{C} 9-\mathrm{H} 12)$ & 1.9880 & $61.92 \%$ & $38.08 \%$ & $0.786,0.617$ & $\mathrm{sp}^{3.03}(\mathrm{C} 9) \mathrm{sp}^{0.00}(\mathrm{H} 12)$ & $\begin{array}{c}\mathrm{s}(24.82 \%)+\mathrm{p}(75.16 \%) \\
\mathrm{s}(99.90 \%)+\mathrm{p}(0.10 \%) \\
\end{array}$ & $0.00(0.02 \%)$ \\
\hline$\sigma(\mathrm{N} 15-\mathrm{H} 16)$ & 1.9938 & $69.87 \%$ & $30.13 \%$ & $0.835,0.548$ & $\mathrm{sp}^{2.24}(\mathrm{~N} 15) \mathrm{sp}^{0.00}(\mathrm{H} 16)$ & $\begin{array}{c}\mathrm{s}(30.86 \%)+\mathrm{p}(69.12 \%) \\
\mathrm{s}(99.77 \%)+\mathrm{p}(0.23 \%)\end{array}$ & $0.00(0.03 \%)$ \\
\hline$\sigma(\mathrm{N} 15-\mathrm{H} 17)$ & 1.9938 & $69.90 \%$ & $30.10 \%$ & $0.836,0.548$ & $\mathrm{sp}^{2.24}(\mathrm{~N} 15) \mathrm{sp}^{0.00}(\mathrm{H} 17)$ & $\begin{array}{c}\mathrm{s}(30.89 \%)+\mathrm{p}(69.08 \%) \\
\mathrm{s}(99.77 \%)+\mathrm{p}(0.23 \%)\end{array}$ & $0.00(0.03 \%)$ \\
\hline LP(O8) & 1.9736 & & & & $\mathrm{sp}^{0.77}$ & $\mathrm{~s}(56.52 \%)+\mathrm{p}(43.46 \%)$ & $0.00(0.02 \%)$ \\
\hline
\end{tabular}

Volume 6 Issue 1, January 2017

www.ijsr.net

Licensed Under Creative Commons Attribution CC BY 
International Journal of Science and Research (IJSR)

ISSN (Online): 2319-7064

Index Copernicus Value (2015): 78.96 | Impact Factor (2015): 6.391

\begin{tabular}{|c|c|c|c|c|c|c|c|}
\hline LP(N15) & 1.8319 & & & & $\mathrm{sp}^{1.00}$ & $\mathrm{~s}(0.00 \%)+\mathrm{p}(100.00 \%)$ & $0.00(0.00 \%)$ \\
\hline$\pi(\mathrm{C} 3-\mathrm{C} 4)$ & 1.6228 & $54.36 \%$ & $45.64 \%$ & $0.737,0.675$ & $\mathrm{sp}^{1.00}(\mathrm{C} 3) \mathrm{sp}^{1.00}(\mathrm{C} 4)$ & $\begin{array}{c}\mathrm{s}(0.00 \%)+\mathrm{p}(99.95 \%) \\
\mathrm{s}(0.00 \%)+\mathrm{p}(99.95 \%)\end{array}$ & $\begin{array}{c}0.00(0.05 \%) \\
0.00(0.07 \%)\end{array}$ \\
\hline$\pi(\mathrm{C} 5-\mathrm{C} 6)$ & 1.6961 & $54.32 \%$ & $45.68 \%$ & $0.737,0.675$ & $\mathrm{sp}^{1.00}(\mathrm{C} 5) \mathrm{sp}^{1.00}(\mathrm{C} 6)$ & $\begin{array}{c}\mathrm{s}(0.00 \%)+\mathrm{p}(99.93 \%) \\
\mathrm{s}(0.00 \%)+\mathrm{p}(99.56 \%)\end{array}$ & $\begin{array}{c}0.00(0.05 \%) \\
0.00(0.07 \%)\end{array}$ \\
\hline$\pi(\mathrm{C} 7-\mathrm{O} 8)$ & 1.9765 & $33.13 \%$ & $66.87 \%$ & $0.575,0.817$ & $\mathrm{sp}^{1.00}(\mathrm{C} 7) \mathrm{sp}^{1.00}(\mathrm{O} 8)$ & $\begin{array}{c}\mathrm{s}(0.00 \%)+\mathrm{p}(99.86 \%) \\
\mathrm{s}(0.02 \%)+\mathrm{p}(99.91 \%)\end{array}$ & $\begin{array}{c}(0.44 \%) \\
0.00(0.14 \%)\end{array}$ \\
\hline LP (O8) & 1.8832 & & & & $\mathrm{sp} 99.99 \mathrm{~s}$ & $\mathrm{~s}(0.02 \%)+\mathrm{p}(99.91 \%)$ & $-0.07 \%$ \\
\hline$\pi(\mathrm{C} 1-\mathrm{C} 2)$ & 1.6516 & $54.20 \%$ & $45.80 \%$ & $0.736,0.676$ & $\mathrm{sp}^{1.00}(\mathrm{C} 1) \mathrm{sp}^{1.00}(\mathrm{C} 2)$ & $\begin{array}{c}\mathrm{s}(0.00 \%)+\mathrm{p}(99.97 \%) \\
\mathrm{s}(0.00 \%)+\mathrm{p}(99.95 \%)\end{array}$ & $\begin{array}{c}0.00(0.03 \%) \\
0.00(0.05 \%)\end{array}$ \\
\hline
\end{tabular}

${ }^{a}$ For numbering of atoms refer Fig. 1

${ }^{b}$ Percentage of s-type and p-type subshell of an atomic orbitals are given in their respective brackets

Table 6: The DFT/ B3LYP/cc-pVDZ and B3LYP/cc-pVTZ level calculated electric dipole moments (Debye), Dipole moments compound, polarizability (in a.u), $\beta$ components and $\beta_{\text {tot }}\left(10^{-30}\right.$ esu)value of (4-Aminophenyl)ethanone

\begin{tabular}{|c|c|c|c|c|c|}
\hline Parameters & $\begin{array}{c}\text { B3LYP/ } \\
\text { cc-pVDZ }\end{array}$ & $\begin{array}{c}\text { B3LYP/ } \\
\text { cc-pVTZ }\end{array}$ & Parameters & $\begin{array}{c}\text { B3LYP/ } \\
\text { cc-pVDZ }\end{array}$ & $\begin{array}{c}\text { B3LYP/ } \\
\text { cc-pVTZ }\end{array}$ \\
\hline$\mu_{\mathrm{x}}$ & -4.7734 & -4.2507 & $\beta_{\mathrm{xxx}}$ & -88.5158 & -71.7445 \\
\hline$\mu_{\mathrm{y}}$ & 2.3352 & 2.4531 & $\beta_{\mathrm{yyy}}$ & -0.1571 & 0.5694 \\
\hline$\mu_{\mathrm{z}}$ & 0.0004 & 0.7748 & $\beta_{\mathrm{zzz}}$ & 0.0004 & 0.5409 \\
\hline$\mu$ & 5.3139 & 4.9685 & $\beta_{\mathrm{xyy}}$ & -17.427 & -18.0187 \\
\hline$\alpha_{\mathrm{xx}}$ & -47.8544 & -52.0256 & $\beta_{\mathrm{xxy}}$ & 18.9802 & 20.4085 \\
\hline$\alpha_{\mathrm{yy}}$ & -55.8095 & -56.0645 & $\beta_{\mathrm{xxz}}$ & 0.0075 & 14.7055 \\
\hline$\alpha_{\mathrm{zz}}$ & -61.6291 & -62.0706 & $\beta_{\mathrm{xzz}}$ & 7.2819 & 7.0806 \\
\hline$\alpha_{\mathrm{xy}}$ & 6.7595 & 7.4095 & $\beta_{\mathrm{yzz}}$ & -1.2067 & -0.9237 \\
\hline$\alpha_{\mathrm{xz}}$ & -0.0015 & -3.5456 & $\beta_{\mathrm{YYZ}}$ & 0.0003 & 0.4766 \\
\hline$\alpha_{\mathrm{yz}}$ & -0.0001 & 0.1352 & $\beta_{\mathrm{XYZ}}$ & -0.0002 & -0.3823 \\
\hline$\Delta \alpha(\mathrm{esu})$ & 280.519388 & 279.114734 & $\beta_{\mathrm{tot}}(\mathrm{esu})$ & $7.4832 \mathrm{E}-30$ & $6.4602 \mathrm{E}-30$ \\
\hline
\end{tabular}

Table 7: Mulliken population analysis of 1(4-Aminophenyl)ethanone performed at B3LYP/cc-pVDZ and B3LYP/cc-pVTZ

\begin{tabular}{|c|c|c|}
\hline \multirow{2}{*}{ Atoms } & \multicolumn{2}{|c|}{ Atomic charges } \\
\cline { 2 - 3 } & B3LYP/cc-pVDZ & B3LYP/cc-pVTZ \\
\hline C1 & -0.561 & -0.523 \\
\hline C2 & 0.206 & 0.175 \\
\hline C3 & -0.248 & -0.247 \\
\hline C4 & 0.683 & 0.658 \\
\hline C5 & -0.224 & -0.225 \\
\hline C6 & 0.184 & 0.159 \\
\hline C7 & 1.083 & 1.093 \\
\hline O8 & -0.772 & -0.791 \\
\hline C9 & -0.105 & -0.107 \\
\hline H10 & 0.003 & 0.007 \\
\hline H11 & 0.003 & 0.006 \\
\hline H12 & 0.006 & 0.011 \\
\hline H13 & 0.035 & 0.043 \\
\hline H14 & 0.008 & 0.019 \\
\hline N15 & -0.786 & -0.756 \\
\hline H16 & 0.203 & 0.192 \\
\hline H17 & 0.204 & 0.193 \\
\hline H18 & 0.007 & 0.018 \\
\hline H19 & 0.070 & 0.075 \\
\hline
\end{tabular}

Table 8: Quantum Chemical Parameters of 1(4-Aminophenyl)ethanone calculated at B3LYP/cc-pVDZ and B3LYP/cc-pVTZ level of theory

\begin{tabular}{|l|c|c|}
\hline \multicolumn{1}{|c|}{ Quantum Chemical Parameters } & B3LYP/ & B3LYP/ \\
CC-PVDZ & CC-PVTZ \\
\hline Ionisation potential(I) $=(-$ Homo energy $)$ & 0.21354 & 0.22231 \\
\hline Electron Affinity $(\mathrm{A})=(-$ Lumo Energy $)$ & 0.03892 & 0.04742 \\
\hline Homo-Lumo Energy gap & 4.7515 & 4.7589 \\
\hline Hardness $(\eta)=0.5 *(\mathrm{I}-\mathrm{A})$ & 0.08731 & 0.087445 \\
\hline Electronegativity $(\mathrm{X})=(\mathrm{I}+\mathrm{A}) / 2$ & 0.12623 & 0.134865 \\
\hline softness $(\sigma)=1 / \eta$ & 11.45344 & 11.43576 \\
\hline Chemical potential $(\mathrm{M})=-\mathrm{X}$ & -0.12623 & -0.13487 \\
\hline GlobalElectrophilicity $(\mathrm{w})=(\mathrm{M} * \mathrm{M}) /($ eta $* 2)$ & 0.09125 & 0.104 \\
\hline
\end{tabular}

Volume 6 Issue 1, January 2017

www.ijsr.net

Licensed Under Creative Commons Attribution CC BY 


\section{International Journal of Science and Research (IJSR) \\ ISSN (Online): 2319-7064}

Index Copernicus Value (2015): 78.96 | Impact Factor (2015): 6.391

Table 9: Magnetic susceptibility of 1(4-Aminophenyl)ethanone at various temperatures.

\begin{tabular}{|c|c|c|c|}
\hline S.NO & $\begin{array}{l}\text { Temp. } \\
\text { (kelvin) }\end{array}$ & $\begin{array}{l}\text { Susceptibility }\left(\chi_{m}\right) \\
\text { mole per } \mathrm{m}^{3}\end{array}$ & $\begin{array}{c}\text { 1/susceptibility } \\
1 /\left(\chi_{\mathrm{m}}\right)\end{array}$ \\
\hline 1 & 10 & $2.6418 \mathrm{E}-05$ & 37852.98 \\
\hline 2 & 20 & $1.3209 \mathrm{E}-05$ & 75705.96 \\
\hline 3 & 40 & $6.6045 \mathrm{E}-06$ & 151411.9 \\
\hline 4 & 60 & $4.403 \mathrm{E}-06$ & 227117.9 \\
\hline 5 & 80 & $3.3023 \mathrm{E}-06$ & 302823.8 \\
\hline 6 & 100 & $2.6418 \mathrm{E}-06$ & 378529.8 \\
\hline 7 & 120 & $2.2015 \mathrm{E}-06$ & 454235.7 \\
\hline 8 & 140 & $1.887 \mathrm{E}-06$ & 529941.7 \\
\hline 9 & 160 & $1.6511 \mathrm{E}-06$ & 605647.7 \\
\hline 10 & 180 & $1.4677 \mathrm{E}-06$ & 681353.6 \\
\hline 11 & 200 & $1.3209 \mathrm{E}-06$ & 757059.6 \\
\hline
\end{tabular}

Table 10: NMR Chemical shielding anisotropy (CSA) parameters of 1(4-Aminophenyl)ethanone

\begin{tabular}{|c|c|c|c|c|c|c|c|c|c|}
\hline Proton & $\sigma_{\mathrm{Tms}}$ & $\begin{array}{c}\text { B3lyp/ } \\
\text { cc-pVDZ } \\
\sigma_{\text {calc }}\end{array}$ & $\begin{array}{c}\delta \text { calc } \\
\left(\sigma_{\mathrm{Tms}}-\sigma_{\text {calc }}\right)\end{array}$ & Exp $\delta_{\text {ppm }}$ & Carbon & $\sigma_{\text {Tms }}$ & $\begin{array}{c}\text { B3lyp/ } \\
\text { cc-pVDZ } \\
\sigma_{\text {calc }}\end{array}$ & $\begin{array}{c}\delta \text { calc } \\
\left(\sigma_{\text {Tms }} \sigma_{\text {calc }}\right)\end{array}$ & Exp $\delta_{\text {ppm }}$ \\
\hline H10 & 31.8821 & 29.5 & 2.3821 & 2.497 & C1 & 182.46 & 31 & 151.46 & 151 \\
\hline H11 & 31.8821 & 29.5 & 2.3821 & 2.497 & C2 & 182.46 & 54 & 128.46 & 127 \\
\hline H12 & 31.8821 & 29.8 & 2.0821 & 2.497 & C3 & 182.46 & 68 & 114.46 & 113 \\
\hline H13 & 31.8821 & 24.1 & 7.7821 & 7.806 & C4 & 182.46 & 52 & 130.46 & 130 \\
\hline H14 & 31.8821 & 25.4 & 6.4821 & 6.646 & C5 & 182.46 & 70 & 112.46 & 113 \\
\hline H16 & 31.8821 & 27.5 & 4.3821 & 4.223 & C6 & 182.46 & 55 & 127.46 & 127 \\
\hline H17 & 31.8821 & 27.6 & 4.2821 & 4.223 & C7 & 182.46 & -14.9 & 197.36 & 196 \\
\hline H18 & 31.8821 & 25.4 & 6.4821 & 6.630 & C9 & 182.46 & 156 & 26.46 & 26 \\
\hline H19 & 31.8821 & 23.9 & 7.9821 & 7.789 & & & & & \\
\hline
\end{tabular}

Table 11: Using Mulliken population analysis: Fukui's fuction $\left(\mathrm{f}_{\mathrm{k}}^{+}, \mathrm{f}_{\mathrm{k}}^{-}, \mathrm{f}_{\mathrm{k}}{ }^{\circ}\right)$, Atomic softness, Electrophilicity of 1(4Aminophenyl) ethanone

\begin{tabular}{|c|c|c|c|c|c|c|c|c|c|c|c|c|c|}
\hline \multicolumn{4}{|c|}{ Mulliken atomic charges(a.u.) } & \multicolumn{4}{|c|}{ Fukui’s functions (a.u.) } & \multicolumn{3}{|c|}{ Atomic softness } & \multicolumn{3}{|c|}{ Electrophilicity indices } \\
\hline Atoms & $\begin{array}{l}\text { Neutral Atomic } \\
\text { charges }(N)\end{array}$ & $\begin{array}{l}\text { Cation } \\
(\mathrm{N}-1)\end{array}$ & Anion $(\mathrm{N}+1)$ & $\mathrm{f}_{\mathrm{k}}^{+}$ & $f_{k}^{-}$ & $\mathrm{f}_{\mathrm{k}}^{\circ}$ & $\Delta \mathrm{f}(\mathrm{r})$ & $\mathrm{s}_{\mathrm{k}}^{+}$ & $\mathrm{s}_{\mathrm{k}}^{-}$ & $\mathrm{s}_{\mathrm{k}}^{\circ}$ & $\omega_{\mathrm{k}}^{+}$ & $\omega_{\mathrm{k}}^{-}$ & $\omega_{\mathrm{k}}{ }^{\circ}$ \\
\hline $\mathrm{C} 1$ & -0.561 & -0.459 & -0.624 & -0.063 & -0.102 & -0.083 & 0.039 & -0.024 & -0.039 & -0.032 & -0.206 & -0.334 & -0.270 \\
\hline $\mathrm{C} 2$ & 0.206 & 0.156 & 0.026 & -0.180 & 0.050 & -0.065 & -0.230 & -0.069 & 0.019 & -0.025 & -0.589 & 0.164 & -0.213 \\
\hline $\mathrm{C} 3$ & -0.248 & -0.015 & -0.136 & 0.112 & -0.233 & -0.061 & 0.345 & 0.043 & -0.090 & -0.023 & 0.366 & -0.762 & -0.198 \\
\hline $\mathrm{C} 4$ & 0.683 & -0.103 & -0.173 & -0.856 & 0.786 & -0.035 & -1.642 & -0.330 & 0.303 & -0.013 & -2.799 & 2.570 & -0.114 \\
\hline $\mathrm{C} 5$ & -0.224 & 0.214 & 0.028 & 0.252 & -0.438 & -0.093 & 0.690 & 0.097 & -0.169 & -0.036 & 0.824 & -1.432 & -0.304 \\
\hline C6 & 0.184 & 0.212 & 0.027 & -0.157 & -0.028 & -0.093 & -0.129 & -0.060 & -0.011 & -0.036 & -0.513 & -0.092 & -0.302 \\
\hline $\mathrm{C} 7$ & 1.083 & -0.499 & -0.666 & -1.749 & 1.582 & -0.084 & -3.331 & -0.674 & 0.609 & -0.032 & -5.719 & 5.173 & -0.273 \\
\hline O8 & -0.772 & 0.352 & 0.246 & 1.018 & -1.124 & -0.053 & 2.142 & 0.392 & -0.433 & -0.020 & 3.329 & -3.675 & -0.173 \\
\hline C9 & -0.105 & 0.362 & 0.235 & 0.340 & -0.467 & -0.064 & 0.807 & 0.131 & -0.180 & -0.024 & 1.112 & -1.527 & -0.208 \\
\hline H10 & 0.003 & 0.159 & -0.196 & -0.199 & -0.156 & -0.178 & -0.043 & -0.077 & -0.060 & -0.068 & -0.651 & -0.510 & -0.580 \\
\hline H11 & 0.003 & 0.831 & 0.737 & 0.734 & -0.828 & -0.047 & 1.562 & 0.283 & -0.319 & -0.018 & 2.400 & -2.708 & -0.154 \\
\hline H12 & 0.006 & -0.019 & -0.037 & -0.043 & 0.025 & -0.009 & -0.068 & -0.017 & 0.010 & -0.003 & -0.141 & 0.082 & -0.029 \\
\hline H13 & 0.035 & 0.555 & 0.492 & 0.457 & -0.520 & -0.032 & 0.977 & 0.176 & -0.200 & -0.012 & 1.494 & -1.700 & -0.103 \\
\hline H14 & 0.008 & -0.236 & -0.301 & -0.309 & 0.244 & -0.033 & -0.553 & -0.119 & 0.094 & -0.013 & -1.010 & 0.798 & -0.106 \\
\hline N15 & -0.786 & -0.257 & -0.315 & 0.471 & -0.529 & -0.029 & 1.000 & 0.181 & -0.204 & -0.011 & 1.540 & -1.730 & -0.095 \\
\hline H16 & 0.203 & -0.254 & -0.314 & -0.517 & 0.457 & -0.030 & -0.974 & -0.199 & 0.176 & -0.012 & -1.691 & 1.494 & -0.098 \\
\hline H17 & 0.204 & -0.251 & -0.313 & -0.517 & 0.455 & -0.031 & -0.972 & -0.199 & 0.175 & -0.012 & -1.691 & 1.488 & -0.101 \\
\hline H18 & 0.007 & -0.248 & -0.312 & -0.319 & 0.255 & -0.032 & -0.574 & -0.123 & 0.098 & -0.012 & -1.043 & 0.834 & -0.105 \\
\hline H19 & 0.07 & -0.245 & -0.311 & -0.381 & 0.315 & -0.033 & -0.696 & -0.147 & 0.121 & -0.013 & -1.246 & 1.030 & -0.108 \\
\hline
\end{tabular}

Table 12: Statistical thermodynamic parameters of 1(4-Aminophenyl)ethanone at various temperatures, performed at B3LYP/cc-pVDZ

\begin{tabular}{|c|c|c|c|c|}
\hline \multicolumn{5}{|c|}{ Thermodynamic parameters $\left(\mathrm{k} \mathrm{cal} \mathrm{mol}{ }^{-1}\right)$} \\
\hline Temp. (Kelvin) & $\mathrm{C}_{\mathrm{P}}$ & $\mathrm{S}$ & $\left(\mathrm{H}^{\mathrm{o}}-\mathrm{E}^{\mathrm{o}}{ }_{\mathrm{o}}\right) / \mathrm{T}$ & $\left(\mathrm{G}_{\mathrm{o}}-\mathrm{E}_{\mathrm{o}}^{\mathrm{o}}\right) / \mathrm{T}$ \\
\hline 20 & 9.327 & 52.645 & 7.978 & -44.667 \\
\hline 40 & 11.619 & 59.102 & 8.310 & -50.792 \\
\hline 60 & 13.672 & 63.775 & 8.953 & -54.822 \\
\hline 80 & 15.570 & 67.808 & 9.820 & -57.988 \\
\hline 100 & 17.476 & 71.523 & 10.853 & -60.670 \\
\hline
\end{tabular}

Volume 6 Issue 1, January 2017 www.ijsr.net

Licensed Under Creative Commons Attribution CC BY 
International Journal of Science and Research (IJSR)

ISSN (Online): 2319-7064

Index Copernicus Value (2015): 78.96 | Impact Factor (2015): 6.391

\begin{tabular}{|c|c|c|c|c|}
\hline 120 & 19.441 & 75.058 & 12.015 & -63.043 \\
\hline 140 & 21.462 & 78.482 & 13.280 & -65.202 \\
\hline 160 & 23.525 & 81.837 & 14.633 & -67.204 \\
\hline 180 & 25.621 & 85.150 & 16.061 & -69.089 \\
\hline 200 & 27.743 & 88.437 & 17.555 & -70.882 \\
\hline
\end{tabular}

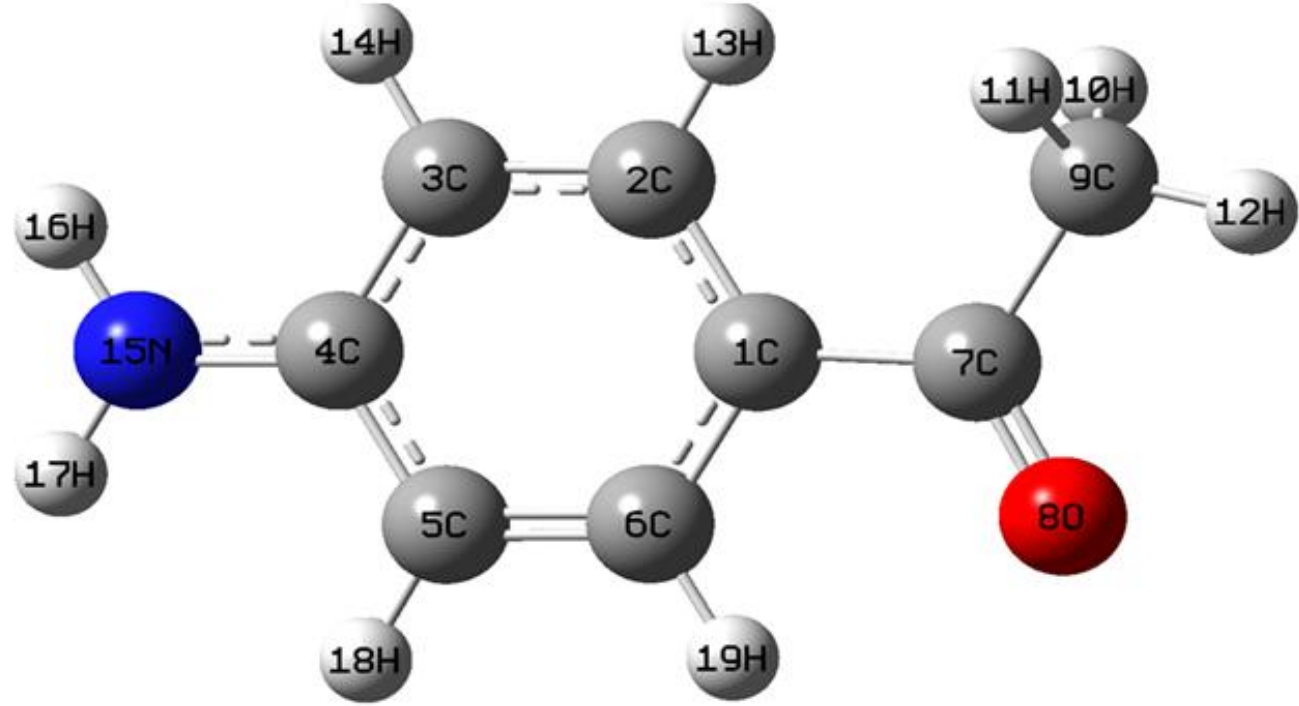

Figure 1: Optimized geometrical structure and atom numbering of 1(4-aminophenyl)ethanone

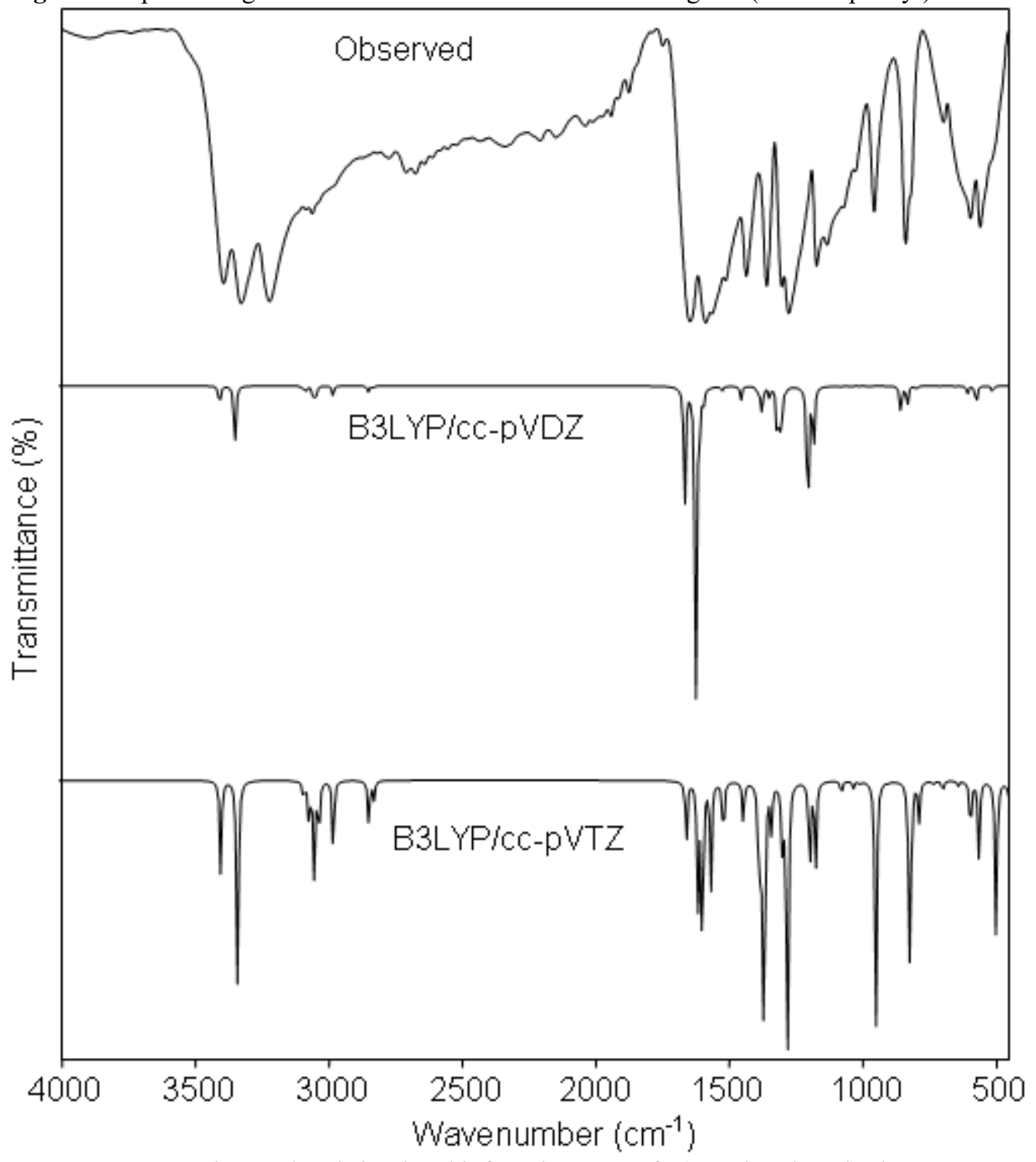

Figure 2: Observed and simulated infrared spectra of 1(4-aminophenyl)ethanone

Volume 6 Issue 1, January 2017 www.ijsr.net

Licensed Under Creative Commons Attribution CC BY 
International Journal of Science and Research (IJSR)

ISSN (Online): 2319-7064

Index Copernicus Value (2015): 78.96 | Impact Factor (2015): 6.391
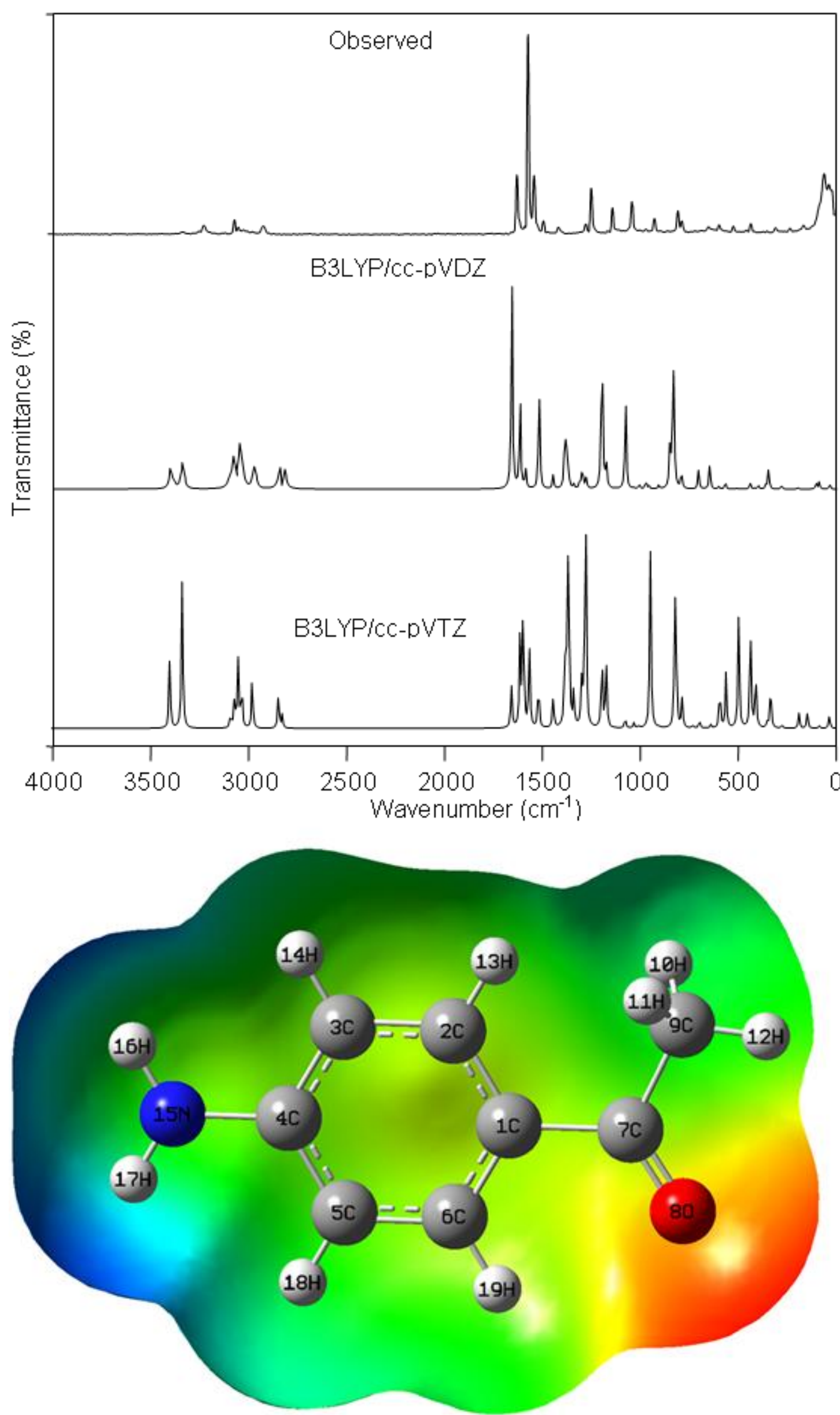

Figure 4 (a): Molecular Electrostatic Potential of 1(4-aminophenyl)eethanone

Volume 6 Issue 1, January 2017 www.ijsr.net

Licensed Under Creative Commons Attribution CC BY 


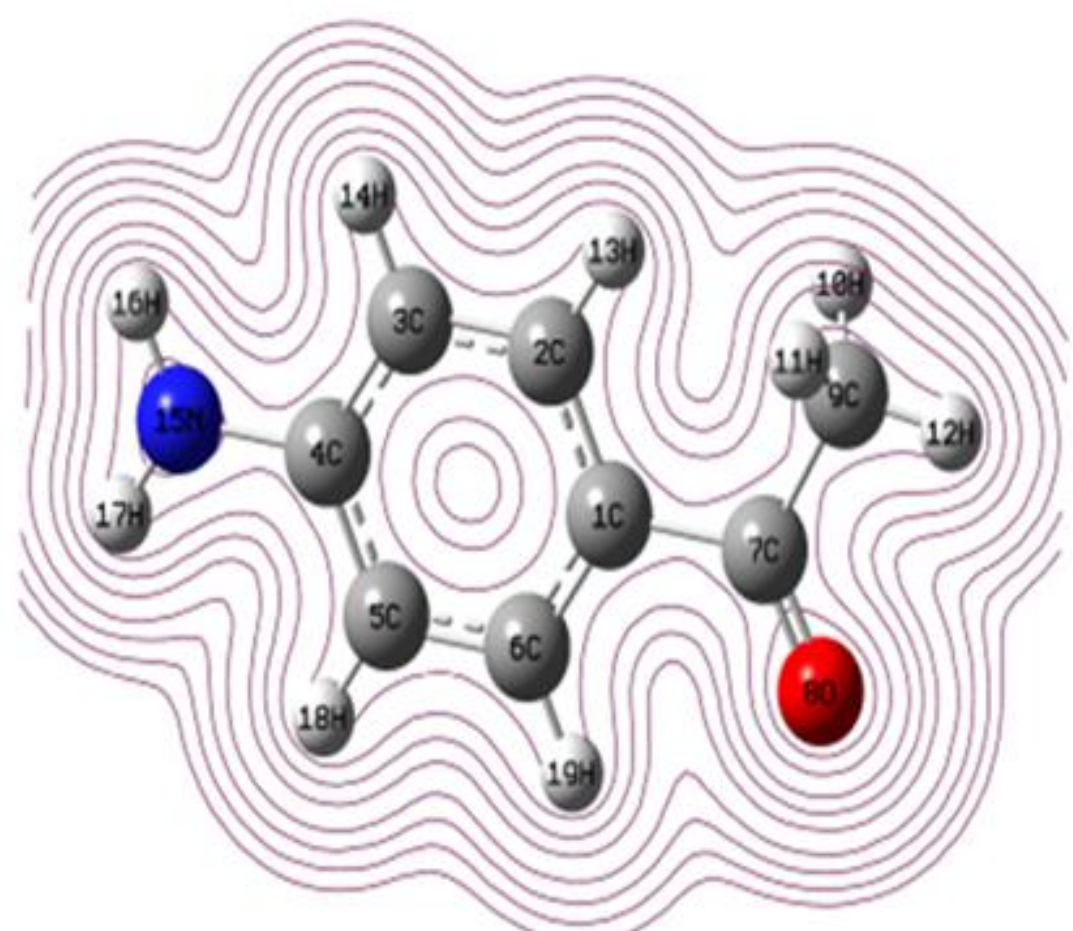

Figure 4 (b): Molecular electrostatic potential contour map of 1(4-aminophenyl)ethanone

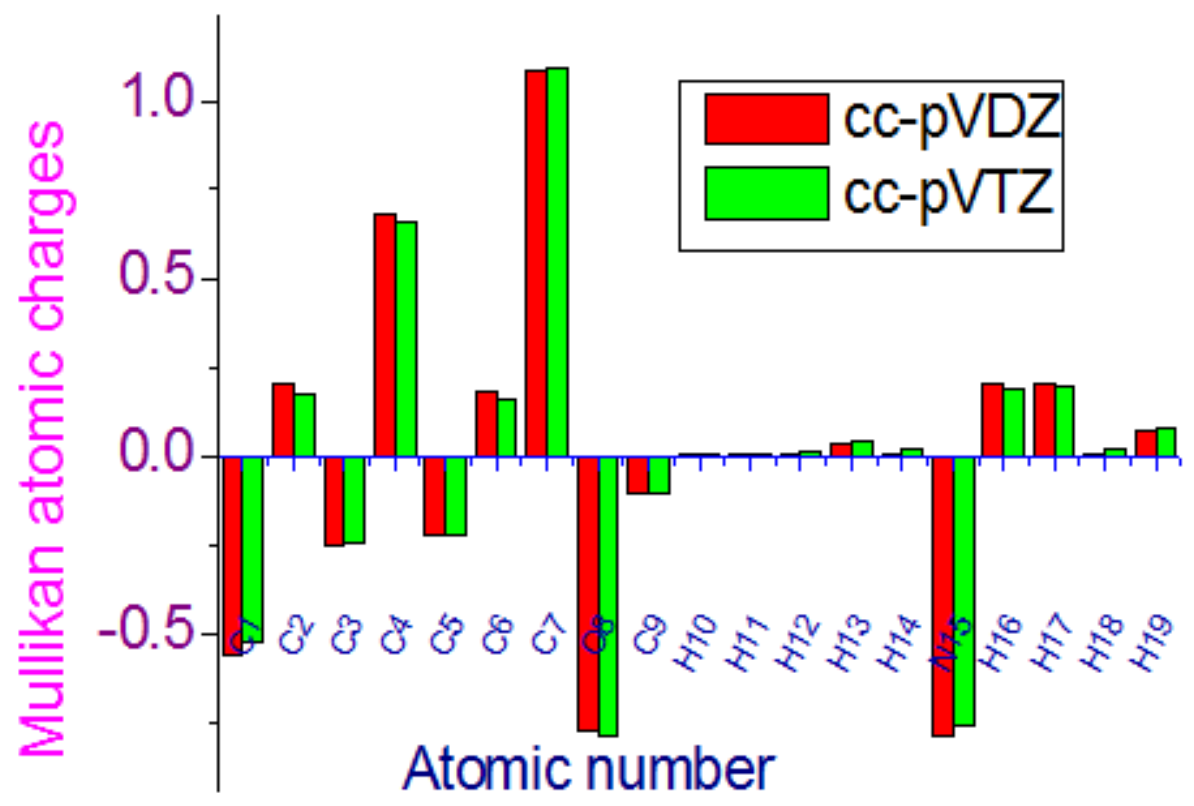

Figure 5: Mullikan atomic charges of 1(4-Aminophenyl)ethanone

Volume 6 Issue 1, January 2017 www.ijsr.net 
International Journal of Science and Research (IJSR)

ISSN (Online): 2319-7064

Index Copernicus Value (2015): 78.96 | Impact Factor (2015): 6.391
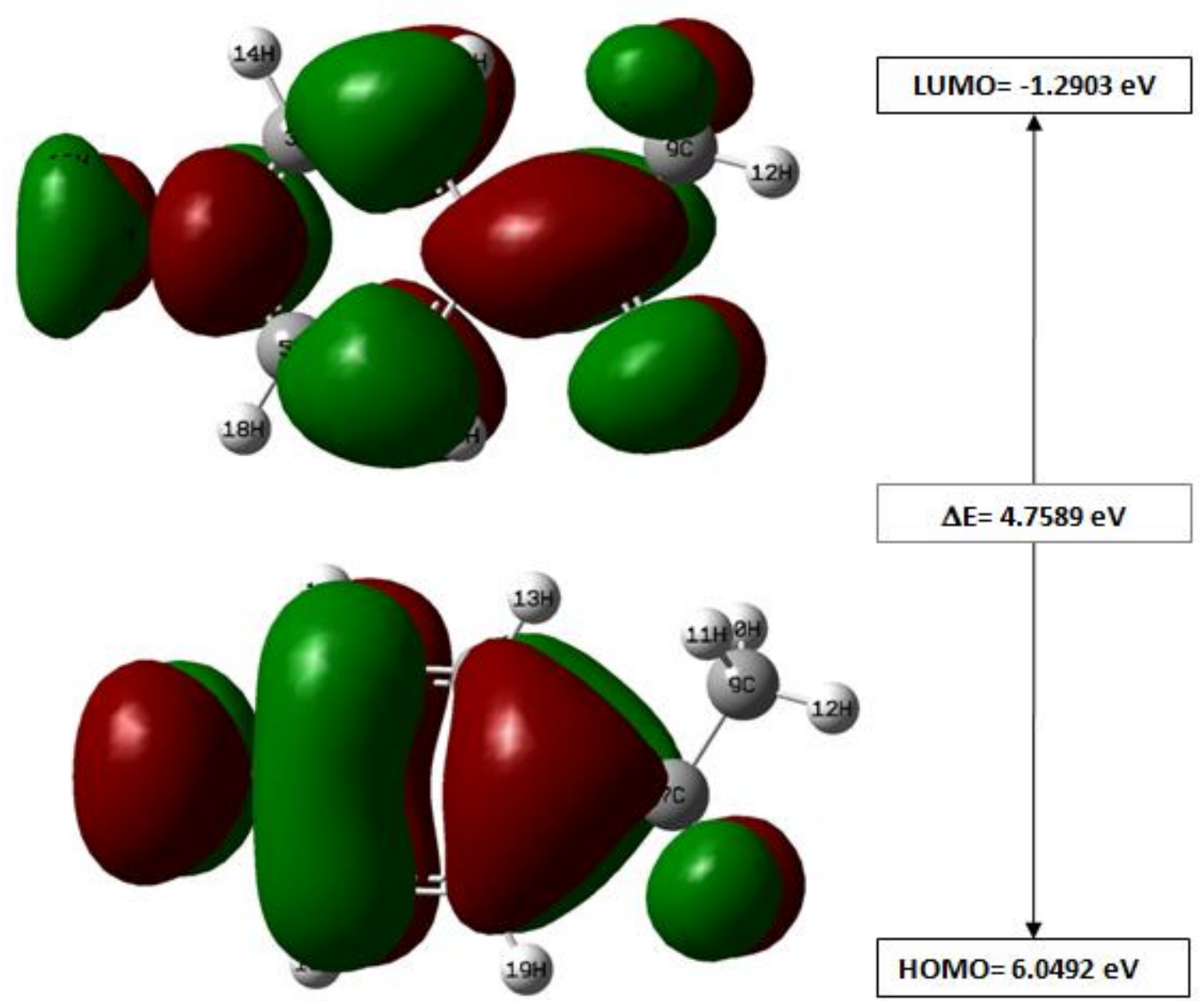

Figure 6: HOMO-LUMO plot of 1(4-aminophenyl)ethanone

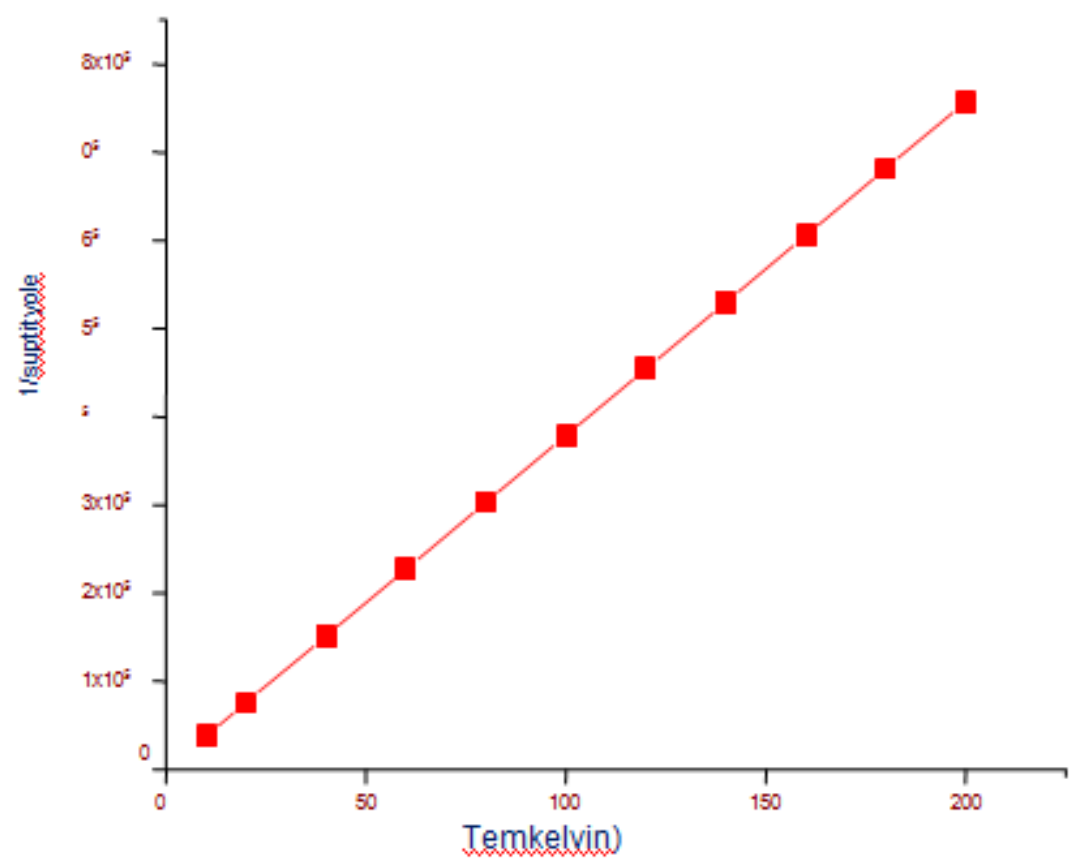

Figure 7: Magnetic susceptibility of 1(4-aminophenyl)ethanone

Volume 6 Issue 1, January 2017 www.ijsr.net

Licensed Under Creative Commons Attribution CC BY 
International Journal of Science and Research (IJSR)

ISSN (Online): 2319-7064

Index Copernicus Value (2015): 78.96 | Impact Factor (2015): 6.391

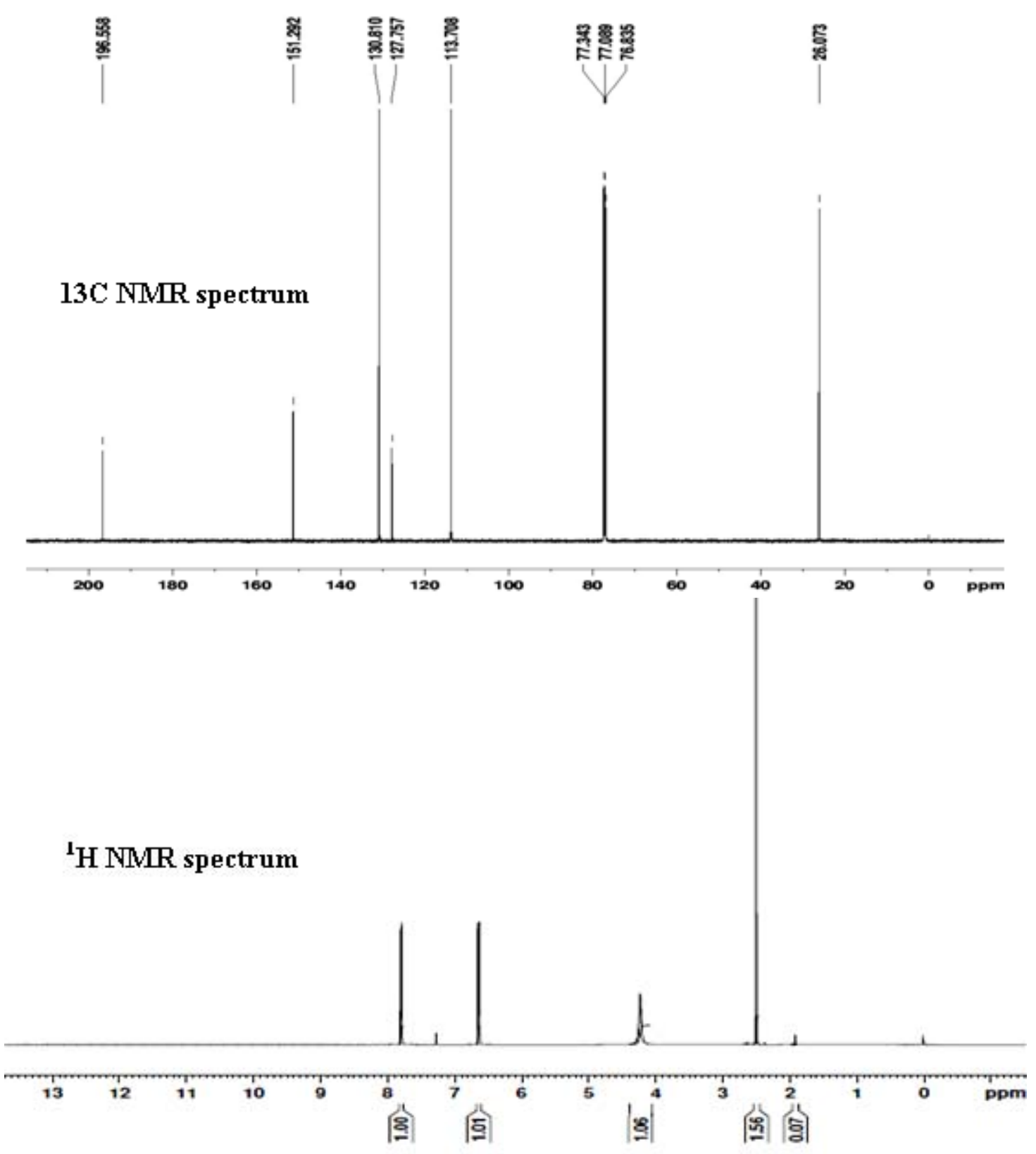

Figure 8: ${ }^{13} \mathrm{C}$ and ${ }^{1} \mathrm{H}$ NMR spectra of the of 1(4-aminophenyl)ethanone

Volume 6 Issue 1, January 2017

www.ijsr.net

Licensed Under Creative Commons Attribution CC BY 


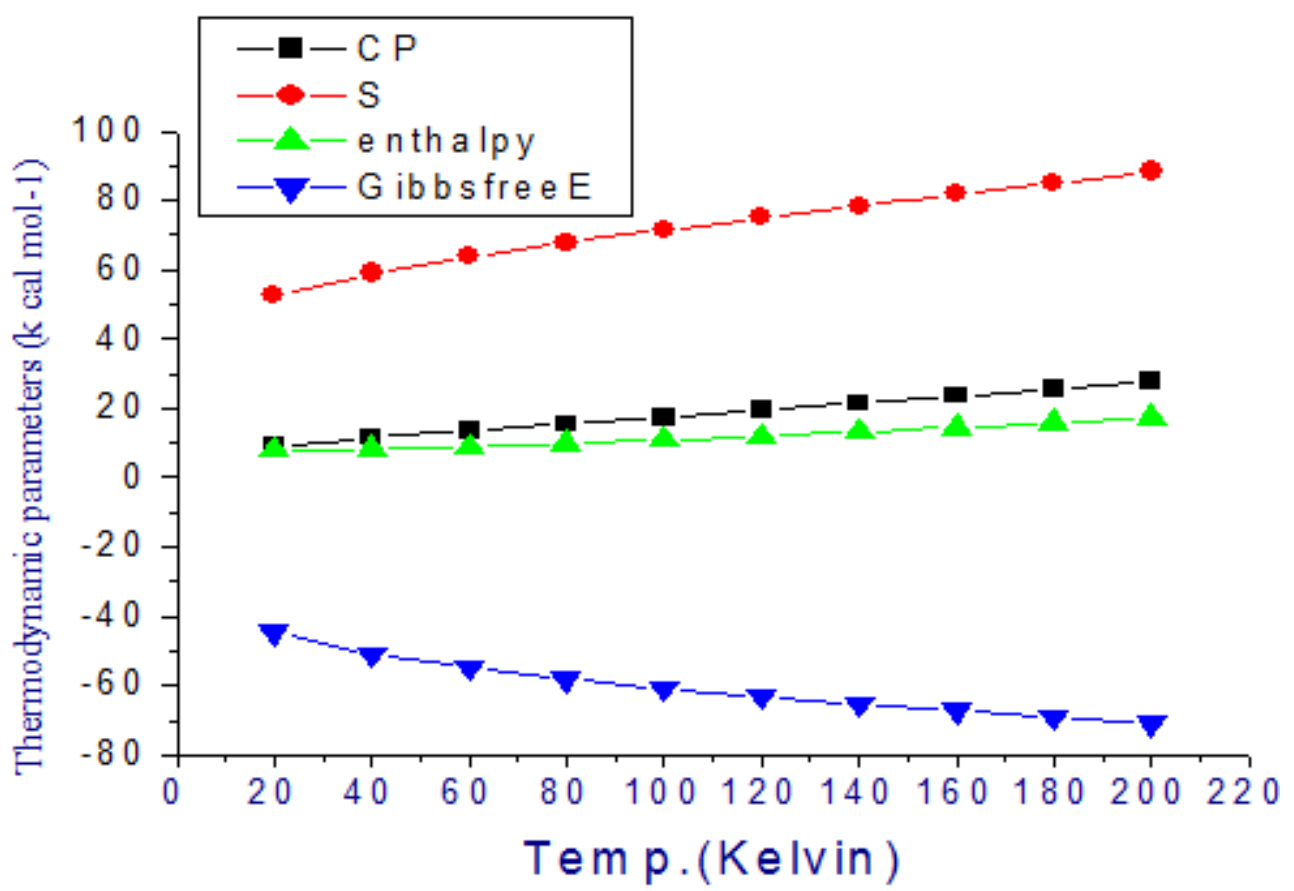

Figure 9: Thermodynamic properties of 1(4-aminophenyl)ethanone

Volume 6 Issue 1, January 2017 www.ijsr.net 